\title{
Development of a Safety-Inspection Method for River Bridges in Turkey
}

\author{
Huseyin Akay ${ }^{1}$, Musteyde Baduna Kocyigit ${ }^{1}$ and A. Melih Yanmaz ${ }^{2, *}$ \\ 1 Civil Engineering Department, Gazi Universitesi, Maltepe, Cankaya, 06570 Ankara, Turkey; \\ hakay@gazi.edu.tr (H.A.); baduna@gazi.edu.tr (M.B.K.) \\ 2 Civil Engineering Department, Orta Dogu Teknik Universitesi, Dumlupinar Blv. No:1, 06800 Ankara, Turkey \\ * Correspondence: myanz@metu.edu.tr; Tel.: +90-312-210-5445
}

Received: 30 July 2019; Accepted: 6 September 2019; Published: 12 September 2019

\begin{abstract}
In this paper, findings of a research project about river bridges in Turkey are shared and details of the developed safety-inspection method based on hydrological and hydraulic factors are presented. In the project, the Western Black Sea Basin was chosen as the pilot area, where the basin is mountainous with steep slopes and has a rainy climate with frequent flash floods. Many river bridges in the basin were inspected at different flow conditions throughout the project duration of three years. The developed safety-inspection method is composed of four main parts: evaluation of watershed hydrology and its flood potential, stream stability, bridge characteristics and a rapid scour assessment. A structural assessment is also included in the method. Five river bridges in the area were chosen for detailed inspection and application of the method. Results showed that the method was capable of identifying and ranking the bridges in regard to maintenance needs and forming a comprehensive inventory for bridge engineers.
\end{abstract}

Keywords: hydraulic assessment; hydrologic assessment; river bridges; safety-inspection; scour assessment; Western Black Sea Basin

\section{Introduction}

After failure of Caycuma Bridge pier in April 2012 that resulted in the death of 15 people, problems of river bridges attracted further attention in Turkey. Since then, severe damages or failures of some river bridges have been reported, especially in the Black Sea Basin of the country. This basin is mountainous with steep slopes and has a rainy climate with frequent flash floods. With an increasing number of bridge disasters, the General Directorate of Highways (GDH) introduced a bridge management system (BMS) in 2017 in which all structural data of bridges in Turkey were transferred to the system, with the information about the requirements of the inspection/repair needs of the bridges, and the cost of maintenance. In this system, each subsidiary component of the bridge is inspected and graded visually or with equipment, where necessary, according to deterioration, aging, damage and loss of elements. Meanwhile, a collaborative research project with GDH and two universities was conducted with duration of three years to investigate the problems of river bridges in Turkey with extensive field observations and measurements in the Western Black Sea Region [1]. The study noted that almost all bridge failures in Turkey are river bridges and these were caused by various hydraulic factors, mainly excessive scouring around bridge piers, and debris accumulation. Along with this study, Akay [2] developed a safety-inspection method for river bridges that could be implemented into the current BMS to inspect bridges, especially with regard to hydraulic effects, and to form an inventory consisting of hydrologic and hydraulic factors and their effects on the structure.

Many countries developed their own BMSs depending on their needs, to manage their bridge stock efficiently, while some countries adopted widely used well-known systems of other countries [3-6]. In a 
traditional BMS, there are four modules: inventory, inspection, maintenance and optimization. Among those modules, inventory is considered as the most important part in which detailed database of all attributes of the bridge elements are collected [7]. Thus, various countries all over the world, such as France, Italy, Taiwan and India are still attempting to develop their national bridge database to improve their asset management [8-10]. Currently consisting of 28-member countries, the European Union has a wide variety of infrastructure assets with different construction types and BMSs. The majority of those BMSs focused mainly on structural health monitoring with less consideration for water-related hazards, such as scour at bridge foundation, and debris accumulation [11]. Meanwhile, some studies were conducted on the extreme weather events and changes in the frequency of extreme flooding due to global warming and the potential risks they pose to bridges [12-14]. Thus, today emphasis is placed on the bridge scour assessment with the increase in the number of catastrophic failures of bridges associated with flood induced events. Various studies were conducted to assess stream stability and channel conditions, while, especially in the last decade or so, research has focused on the development of bridge scour assessment methods and the estimation of bridge scour vulnerability [15-23].

In 1995, Lagasse et al. [24] proposed a three-level approach to assess the channel stability in vicinity of bridges, in which geomorphic concepts and qualitative analysis in Level 1, hydrologic, hydraulic and sediment transport aspects in Level 2, and mathematical and physical modelling studies in Level 3 were assessed. This approach is implemented in HEC-20 which is a widely known manual for identifying stream stability problems and presenting guidelines for bridge owners in the USA. According to this approach, stream characteristics and land use changes are considered for an overall stability with the analysis of vertical and lateral stability and stream response, with a number of parameters considered for characterization of the watershed response and morphological evolution. Rosgen [25] proposed a method based on assessing the stability of a stable reach as a reference and then performing a departure analysis to an unstable reach of the same stream type. Montgomery and MacDonald [26] developed a diagnostic approach in which the system and its elements were defined and assessed. Johnson [27] developed a preliminary assessment method based on the previous research related with stream stability and rating channel stability in the vicinity of the bridges located across the USA. In that study, Johnson [27] assessed the channel stability using thirteen indicators of watershed and floodplain activity and characteristics, flow habit, channel pattern and entrenchment or channel confinement, following the concept of Montgomery and MacDonald [26] who stated that geomorphic conditions, such as confinement and entrenchment, played an important role in characterizing channel stability. Furthermore, Shields et al. [28] stated that watershed characteristics were crucial for assessing the existing and future channel stability. In all these approaches, watershed response was very limitedly considered, and focus was mainly on the stream stability. Moreover, various prediction methodologies, such as simulating the temporal variations of the total scour depth under unsteady flow conditions or introducing a dimensionless effective work done by the flow on the sediment bed around the pier, were developed for bridge scour assessment, which are applicable under complex hydraulic/hydrological conditions, and limited scour field data [29-35]. In a study, Bekic et al. [36] applied two different methods of bridge scour assessment, namely the Colorado method [37] and the modified BA 74/06 method [38], on 100 railway bridges located over watercourse and showed that the resulting scour rankings differed for $20 \%$ of bridges with a significant difference of ranking in $10 \%$ of cases.

Within the European framework programs, many projects were carried out to meet the demands of a growing bridge stock and the need for future traffic demands [39]. One of these projects was the BRIDGE SMS: Intelligent bridge maintenance and management system which aimed to provide standardized methods for the assessment of bridge scour risk and implement common procedures among different organizations [40]. In this method, standardized procedures for structural and scour inspection were developed, allowing for four different inspection levels for scour inspection and evaluation, with the complexity and comprehensiveness of the inspections increasing with the levels. Level 1-general inspection, is comprised of 11 structural elements and 11 scour components. In 
a case where a structure Level 1 inspection is not adequate, then the assessment is progressed to detailed inspection, in which 14 individual structural elements are considered throughout scour inspection in Level 2. This level evaluates and records general scour, constriction scour and local scour. The procedure for inspecting bridge elements and components include a detailed visual assessment [41] and a detailed scour inspection, requiring inputs of river bed levels, foundation depth and data on general river channel instabilities. The condition rating between very good (0) to failed (5) is calculated separately for the structural and scour aspect and is accompanied with the time for the next inspection and the assessment of maintenance/repair costs. The scour condition is graded by a custom algorithm in Level 1 and by a risk-based matrix in Level 2, combining the result of the general, constriction and total scour. In the literature, there are many methods and systems, ranging from simple to advanced levels, using sophisticated measuring equipment and techniques. Hence, each country has to decide on the scope of their BMS according to their needs, future projections and budget limits.

In Turkey, a practical, simple but comprehensive method that involves various parameters and characteristics of watershed to enable assessment of the hydrological behavior and flash flood potential of the watershed is necessary for successful asset management. Thus, a simple approach similar to that of Johnson [27] was adopted. However, many indicators of not just stream, but watershed, bridge and environmental characteristics were taken into consideration to form an inclusive database of the bridge stock, as done in more comprehensive systems. The method allowed for two levels, as in many systems. Level 1 is comprised of a basic assessment of all bridge stock while Level 2 is performed in case the result of the Level 1 inspection is found to be insufficient. The method lacks a detailed scour assessment method in Level 1, which is considered in Level 2.

The goals of this study are to share findings of the aforementioned collaborative research project and present the developed safety-inspection algorithm, especially based on hydraulic indicators for river bridges in Turkey. Many river bridges located in the Western Black Sea Basin were inspected at different flow conditions throughout the project duration of three years. According to the problems encountered and observations made, the developed safety-inspection method was composed of four main parts: evaluation of watershed hydrology and its flood potential, stream stability, bridge characteristics and a rapid scour assessment. A structural assessment algorithm different from the current method in the BMS was also incorporated. These comprise the Level 1 of the developed safety-inspection algorithm. Five river bridges whose inventory data are partially available and either had a serious maintenance work during their service life or still have some problems and were inspected from time to time by GDH were chosen in the pilot area. These bridges were inspected in detail throughout the project duration to test the applicability of the method and its capability.

\section{Development of the Safety-Inspection Method}

\subsection{Field Study}

Many river bridges in the Western Black Sea Basin were observed at different flow conditions throughout the study, about ten times in three years. During field trips, characteristics of the watersheds, stream flow, environmental or human induced factors affecting bridges and bridge characteristics were observed. Among those inspected bridges, five of them whose details are given in Table 1 and shown in Figure 1, were selected for full inspection and the application of the developed method.

The bathymetry of stream bed and scour holes around piers and abutments was also measured to track changes in stream beds in the vicinity of bridges, and possible settlements at the structures. Field measurements were conducted by a private company. Measurements of stream bed elevation including scour holes, coordinates of the location and mean water level were performed across and along the stream in the vicinity of the bridge concerned, at frequent intervals using a GPS coupled instrument situated at the reach of the stream. Similar measurements were also performed at the same coordinates during subsequent field visits. However, no noteworthy change in stream bed was noted during this three-year period. 
Table 1. River bridges inspected in the pilot area of the study.

\begin{tabular}{ccccc}
\hline Bridge & Location & Province & Stream & Age (Year) \\
\hline Bartin I & $41^{\circ} 37^{\prime} 24.47^{\prime \prime} \mathrm{N} 32^{\circ} 20^{\prime} 00.42^{\prime \prime} \mathrm{E}$ & Bartin & Gokirmak & 39 \\
Bartin III & $41^{\circ} 38^{\prime} 28.62^{\prime \prime} \mathrm{N} 32^{\circ} 21^{\prime} 20.60^{\prime \prime} \mathrm{E}$ & Bartin & Kocanaz & 34 \\
Catalzeytin & $41^{\circ} 57^{\prime} 10.59^{\prime \prime} \mathrm{N} 34^{\circ} 13^{\prime} 39.69^{\prime \prime} \mathrm{E}$ & Kastamonu & Akcay & 55 \\
Filyos V & $41^{\circ} 12^{\prime} 06.89^{\prime \prime} \mathrm{N} 32^{\circ} 22^{\prime} 35.19^{\prime \prime} \mathrm{E}$ & Karabuk & Yenice & 28 \\
Gokcebey & $41^{\circ} 18^{\prime} 25.90^{\prime \prime} \mathrm{N} 32^{\circ} 07^{\prime} 34.80^{\prime \prime} \mathrm{E}$ & Zonguldak & Yenice & 63 \\
\hline
\end{tabular}

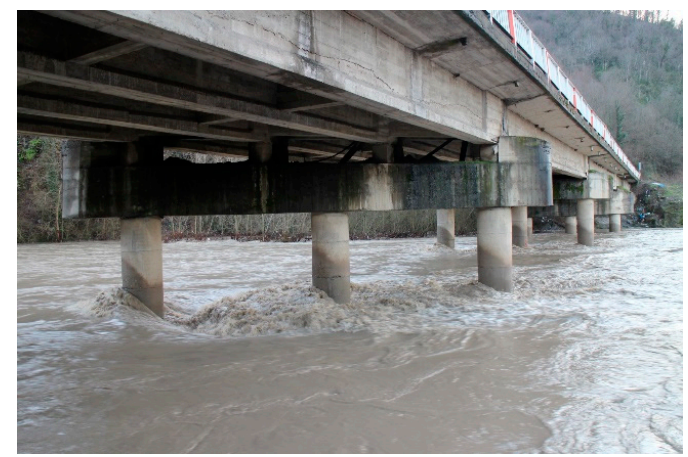

(a)

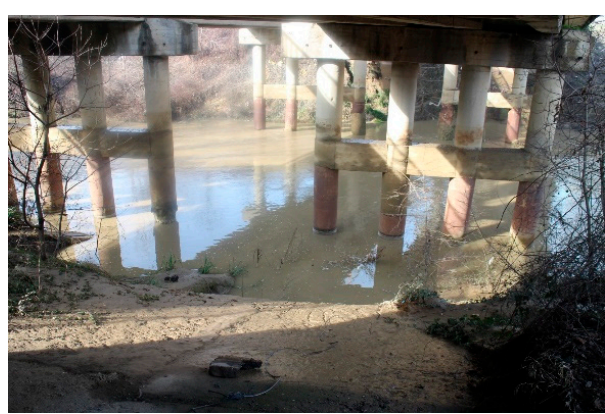

(c)

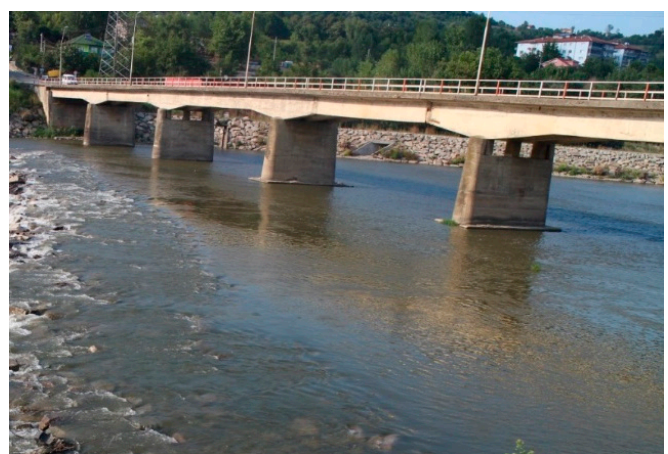

(b)

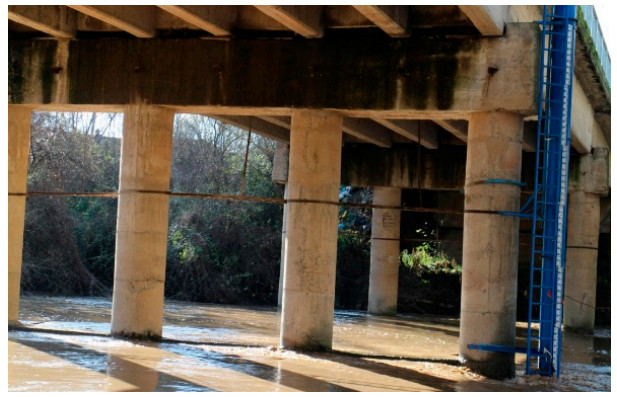

(d)

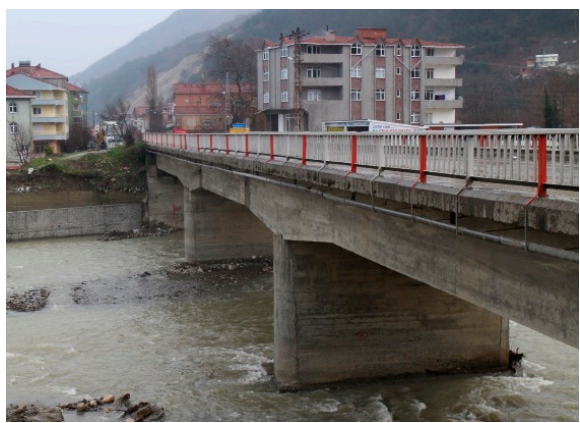

(e)

Figure 1. Bridges selected for full inspection: (a) Filyos V Bridge (April 2016); (b) Gokcebey Bridge (August 2017); (c) Bartin I Bridge (April 2017); (d) Bartin III Bridge (December 2014); (e) Catalzeytin Bridge (February 2016).

\subsection{Safety-Inspection Study}

The current safety-inspection method for bridges in Turkey lacks the consideration of the functionality of the bridges. Therefore, the developed methodology was especially designed for river bridges in which various hydrologic and hydraulic factors were considered. As Johnson [27] pointed out that overall evaluation of river bridges should include stability indicators, starting at watershed characteristics or vertical and lateral aspects of the channel; the current method involved 
four main parts, all concentrated on hydrological and hydraulic factors. The first part involved a hydrological assessment of the watershed and flood potential while the second and third parts consisted of the stability indicators of stream and bridge characteristics, respectively, that were determined or modified using past studies in the literature, lessons learned from failures of river bridges in Turkey, and observations from field studies. During evaluation of the indicators, characteristics of the indicator in the upstream and downstream parts of the bridge were assessed. In the last part, a rapid scour check was carried out to determine scour susceptibility of the bridges. Besides hydrological and hydraulic assessment, a structural evaluation of the river bridges was also included, which was composed of evaluation of main body, and earth retaining and serviceability components of bridges in regard to loss, damage, aging and deformation. According to the developed methodology, the hydrological and hydraulic assessment with the structural evaluation formed the Level 1 assessment. Depending on the results of Level 1, the bridge owner is directed to the Level 2 assessment, if necessary, for a detailed bridge scour analysis and numerical modelling of flow and sediment transport. In this study, only Level 1 was conducted.

\subsection{Hydrologic Assessment of Watershed Characteristics}

Hydrological assessment of a watershed with the outlet located at river bridge section was performed using several hydrological indicators, such as morphometric index, watershed land use and vegetation cover, physical structure, watershed precipitation magnitude and type, landslide and flood history, and water detention/retention structures in the watershed, as given in Table 2. Morphometric index (MI), a parameter, was introduced to estimate the flash flood potential of the watershed using selected morphometric parameters, such as bifurcation ratio $\left(\mathrm{R}_{\mathrm{b}}\right)$, drainage density $\left(D_{d}\right)$, stream frequency $\left(F_{s}\right)$, texture ratio $(T), \rho$ coefficient, length of overland flow $($ Lo $)$, elongation ratio $\left(\mathrm{E}_{\mathrm{r}}\right)$, shape factor $\left(\mathrm{S}_{\mathrm{f}}\right)$, form factor $\left(\mathrm{F}_{\mathrm{f}}\right)$, compactness coefficient $\left(\mathrm{C}_{\mathrm{c}}\right)$, circularity ratio $\left(\mathrm{C}_{\mathrm{r}}\right)$ and width to length ratio $\left(\mathrm{WL}_{\mathrm{r}}\right)$. MI was calculated as the average of the ranks of those morphometric parameters. Other hydrological indicators were complementary features affecting rainfall-runoff process and soil erosion. Then, a hydrological grade (HG) was introduced for rating the overall watershed hydrology and flash flood potential of that watershed. HG was computed by summing up the ranking values (RV) of the five indicators given in Table 2. Since the RV of each of these five indicators ranged between 1 and 12 , HG can have a minimum of 5 and a maximum of 60 .

Table 2. Assessment of watershed hydrology and flash flood potential [42].

\begin{tabular}{|c|c|c|c|c|c|c|c|}
\hline \multicolumn{8}{|c|}{ Watershed Hydrology and Flash Flood Potential } \\
\hline \multirow{3}{*}{ Indicator } & \multicolumn{7}{|c|}{ Classification } \\
\hline & Excellent & \multicolumn{2}{|c|}{ Good } & \multicolumn{2}{|c|}{ Fair } & \multicolumn{2}{|c|}{ Poor } \\
\hline & 3 & 4 & 6 & 7 & 9 & 10 & 12 \\
\hline $\begin{array}{l}\text { Morphometric } \\
\text { Index (MI) }\end{array}$ & $0<\mathrm{MI} \leq 3$ & \multicolumn{2}{|c|}{$3<\mathrm{MI} \leq 6$} & \multicolumn{2}{|c|}{$6<\mathrm{MI} \leq 9$} & \multicolumn{2}{|c|}{$9<\mathrm{MI} \leq 12$} \\
\hline $\begin{array}{l}\text { Watershed } \\
\text { land use }\end{array}$ & $\begin{array}{l}\text { Undisturbed watershed, no } \\
\text { or little human activities }\end{array}$ & \multicolumn{2}{|c|}{$\begin{array}{l}\text { Limited loss of forest, minor } \\
\text { change due to agricultural } \\
\text { land, cattle and } \\
\text { human intervention }\end{array}$} & \multicolumn{2}{|c|}{$\begin{array}{l}\text { Noticeable urbanization, } \\
\text { loss of forest, cattle and } \\
\text { agricultural activity }\end{array}$} & \multicolumn{2}{|c|}{$\begin{array}{l}\text { Dense urbanization and } \\
\text { industrialization, agricultural } \\
\text { and livestock activities, } \\
\text { meadow pastures are present }\end{array}$} \\
\hline $\begin{array}{l}\text { Watershed } \\
\text { vegetation } \\
\text { cover and } \\
\text { physical } \\
\text { structure }\end{array}$ & $\begin{array}{l}\text { Natural, little or no change } \\
\text { in vegetation cover mostly } \\
\text { plain or mildly sloped land }\end{array}$ & \multicolumn{2}{|c|}{$\begin{array}{l}\text { Rare deteriorations in } \\
\text { natural structure of } \\
\text { watershed, partially rough } \\
\text { structure with } \\
\text { moderate slope }\end{array}$} & $\begin{array}{l}\text { Fores } \\
\text { increa } \\
\text { mead } \\
\text { plater }\end{array}$ & d, & \multicolumn{2}{|c|}{$\begin{array}{l}\text { Seriously deteriorated or no } \\
\text { regular vegetation cover, } \\
\text { mountainous, steep basin }\end{array}$} \\
\hline $\begin{array}{l}\text { Watershed } \\
\text { precipitation } \\
\text { magnitude, } \\
\text { type, } \\
\text { landslides and } \\
\text { flood history }\end{array}$ & $\begin{array}{l}\text { Most of the year is arid, } \\
\text { rainfalls with long-term and } \\
\text { low intensities, flood } \\
\text { recurrence frequency } \\
\geq 50 \text { years }\end{array}$ & \multicolumn{2}{|c|}{$\begin{array}{l}\text { Short-term and heavy } \\
\text { rainfall in the spring and } \\
\text { autumn, little amount of } \\
\text { snowfall, } 25 \text { years } \leq \text { flood } \\
\text { recurrence frequency } \\
<50 \text { years }\end{array}$} & $\begin{array}{l}\text { In ma } \\
\text { perio } \\
\text { snow, } \\
10 \text { ye } \\
\text { frequ }\end{array}$ & $\begin{array}{l}\text { short } \\
\text { nd } \\
\text { and } \\
\text { ence }\end{array}$ & \multicolumn{2}{|c|}{$\begin{array}{l}\text { Short-term and heavy rainfall } \\
\text { throughout the year, plenty of } \\
\text { snowfall, serious landslides } \\
\text { and flood recurrence } \\
\text { frequency }<10 \text { years }\end{array}$} \\
\hline $\begin{array}{l}\text { Water } \\
\text { retention } \\
\text { structures in } \\
\text { the watershed }\end{array}$ & $\begin{array}{l}\text { No HEPP or dam, only } \\
\text { small capacity of ponds or } \\
\text { flood detention basin and } \\
\text { are remote to the bridge }\end{array}$ & $\begin{array}{l}\text { Ratio } \\
\text { of HE } \\
\text { deten } \\
<0.5 \% \\
\text { the br }\end{array}$ & $\begin{array}{l}\text { area } \\
d \text { in area } \\
\text { in to }\end{array}$ & $\begin{array}{l}\text { Cons } \\
\text { water } \\
<1 \% \\
\text { such } t \\
\text { bridg }\end{array}$ & $\begin{array}{l}.5 \%< \\
\text { in area } \\
\text { ge site } \\
\text { under } \\
\text { ted }\end{array}$ & $\begin{array}{l}\text { Conse } \\
1 \%<1 \\
\text { area } / \mathrm{b} \\
\text { the br } \\
\text { passin } \\
\text { strean }\end{array}$ & $\begin{array}{l}\text { HEPPs, } \\
\text { face } \\
\text { ose to } \\
\text { t flow } \\
\text { nd }\end{array}$ \\
\hline
\end{tabular}


Topographic, land cover/land use maps of the watersheds, meteorological data and flow data were obtained from General Directorate of Mapping, Turkish State Meteorological Service and the General Directorate of State Hydraulic Works, respectively. Further details about the hydrological assessment can be found in Akay and Baduna Kocyigit [42].

\subsection{Indicators of Stream Stability}

Channel cross-section was subdivided into three groups as bed, floodplain and banks, to determine vertical or horizontal stability of the stream. River training structures, material type and cover, formation, and sediment dynamics in the channel sections were considered in this section. Most of the indicators and their classifications were taken from Johnson [27] with small adjustments to their limits depending on the field observations in Turkey for the calibration of the classification of the indicators.

\subsubsection{Stream Bed Characteristics}

Stream bed characteristics consisted of flow habit, stream longitudinal profile, channel pattern, bar development, bed material and protection, as given in Table 3, in which $S$ is the slope of the stream, $\mathrm{F}_{\mathrm{S}}$ is the approximate portion of sand in stream bed, and $\mathrm{w}$ and $\mathrm{y}$ are the stream width and flow depth, respectively.

Although flow habit may be considered as a hydrologic response for stream flow, discharge is mainly an interaction with stream bed. Therefore, this indicator was taken into consideration in this part. For instance, Karaman Bridge in the project area was located on an ephemeral stream and failed due to heavy rain in the dry season. It was also observed that flow habit was seriously affected by hydroelectric power plants (HEPP) and dams in the area, since they could hold or suddenly release water during their operation. Moreover, indicators of stream longitudinal profile, channel pattern, bed material and bar development directly denote flow depth and velocity, sediment transportation mechanism and capacity. Another indicator was chosen as the bed protection structures which might contribute to the grade control of stream bed. However, they may cause accumulation or degradation at low flow periods. For instance, grade control structures located nearby Filyos I Bridge in the pilot area caused huge scour holes and instability of bed in vicinity of the bridge.

\subsubsection{Floodplain Characteristics}

The formation and width of floodplains were selected as indicators as given in Table 4 . These indicators were used to assess the capability of floodplains for carrying excess bankfull discharge. Occupation of these floodplains by some residential units is a common problem in Turkey. This leads to increase in bed-roughness conditions. Therefore, even during moderately frequent flood events, the river flow rises such that the nearby lands become inundated. This problem was also observed in the pilot area, especially near settlements. For instance, the floodplain in the downstream part of Bartin III Bridge was occupied by local people for private use near the stream. During February 2016 flood, this area was entirely inundated. The degree of damages depends on the intensity of all types of properties located at the floodplains. 
Table 3. Stream bed characteristics.

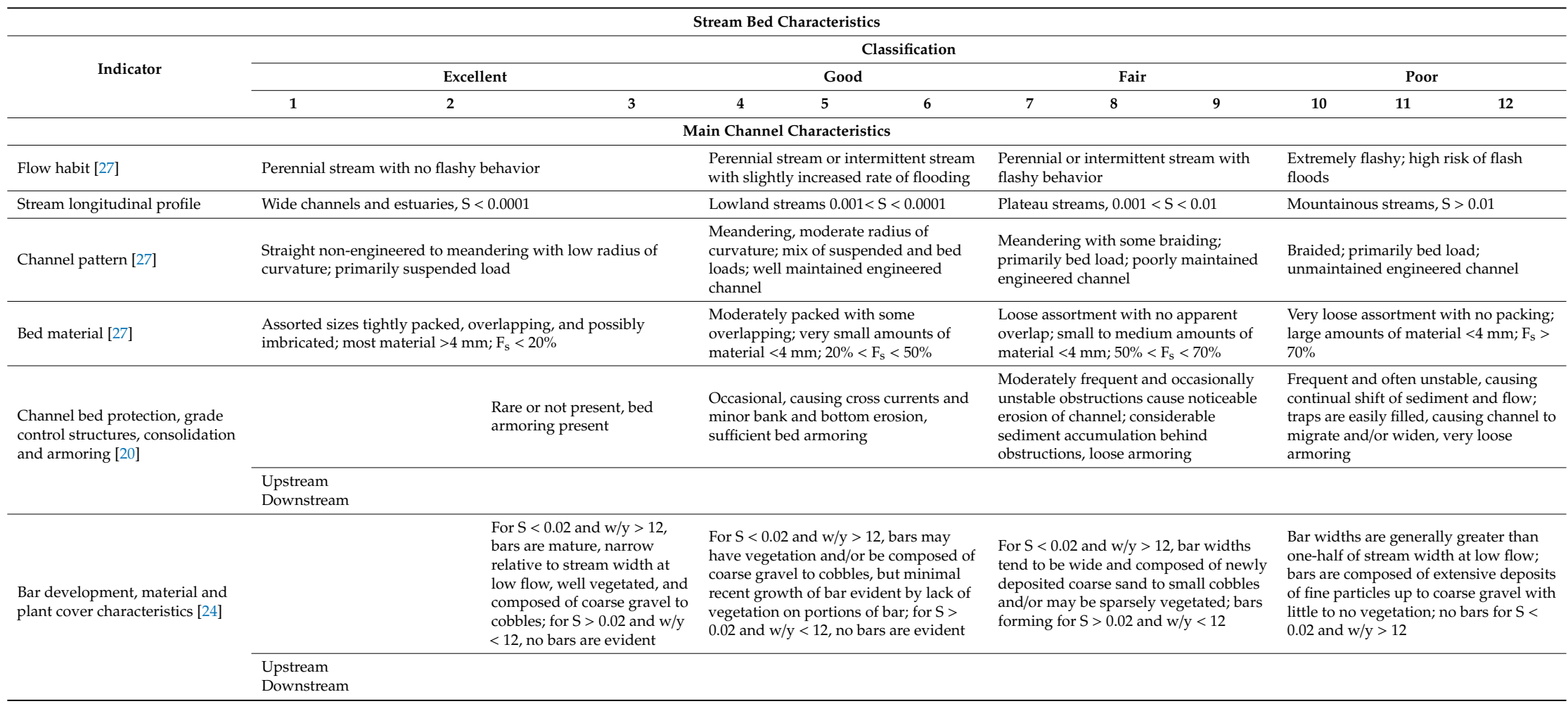


Table 4. Floodplain characteristics.

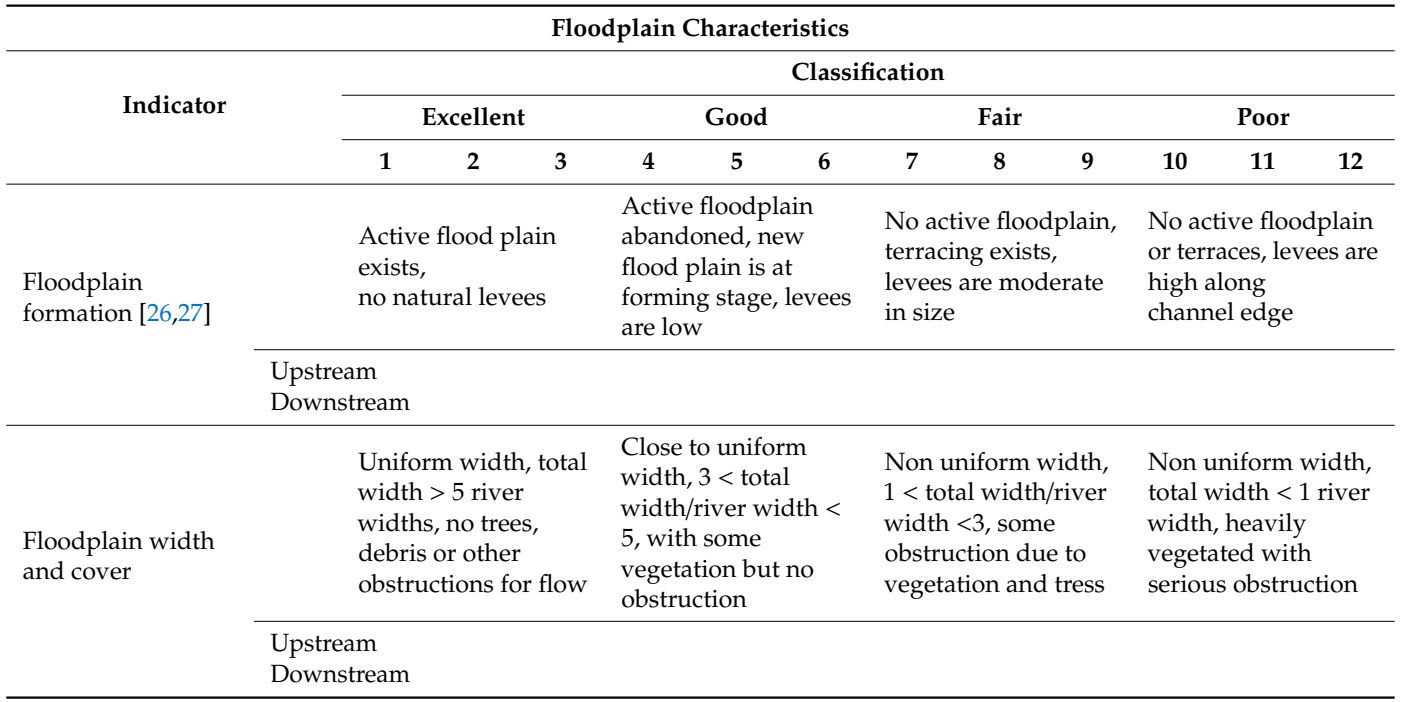

\subsubsection{Stream Bank Characteristics}

Stream banks are the most important components of a channel cross-section for the assessment of the vertical stability of streams. Bank height, average bank slope, vegetative bank protection, soil texture, mass wasting, or bank failure and bank cutting are the dominant indicators for the stability assessment of stream banks, as given in Table 5 .

Instability in stream banks may cause lateral bank erosion, and deepening or widening of channel and floodplain developments due to slumped materials in the bank. Evidence for potential instability for channel banks should be investigated during inspection of river bridges. In this part of the method, the bank stability assessment was adopted from Johnson [27], which was thoroughly studied and tested, while field observations also approved its competence.

\subsubsection{Other Effects}

During field studies, it was observed that some human-induced activities and site-specific channel characteristics resulted in instability problems in vicinity of river bridges. Hence, these types of activities were considered under this heading. These were gravel mining from the stream bed, the presence of stream conjunctions, debris jamming/accumulation, river reclamation, percentage of channel constriction and new bridge construction near the current bridge, as given in Table 6 .

Gravel mining from the stream bed is a common problem, especially in the Western Black Sea Basin. There exists a circular issued by Turkish State Highways, which states that gravel mining from stream beds cannot be performed at $750 \mathrm{~m}$ in upstream and $1000 \mathrm{~m}$ in downstream of the river bridges. However, many bridges in the area are still affected by this practice. For instance, it was observed that a significant amount of bed material is extracted uncontrolled at a site $2 \mathrm{~km}$ downstream of Gokcebey Bridge. 
Table 5. Stream bank characteristics.

\begin{tabular}{|c|c|c|c|c|c|}
\hline \multicolumn{6}{|c|}{ Stream Bank Characteristics } \\
\hline \multirow{3}{*}{ Indicator } & & \multicolumn{4}{|c|}{ Classification } \\
\hline & & Excellent & Good & Fair & Poor \\
\hline & & 3 & 6 & 9 & 12 \\
\hline \multirow{2}{*}{ Bank height } & & Below longitudinal girder of the bridge & $\begin{array}{l}\text { Between longitudinal girder of the } \\
\text { bridge and the deck }\end{array}$ & At bridge deck level & Above bridge railings \\
\hline & $\begin{array}{l}\text { Upstream } \\
\text { Downstream }\end{array}$ & & & & \\
\hline \multirow[t]{2}{*}{ Average bank slope angle [27] } & & $\begin{array}{l}\text { Bank slopes } 3 \mathrm{H}: 1 \mathrm{~V} 18^{\circ} \text { for non-cohesive or } \\
\text { unconsolidated materials to } 1: 145^{\circ} \text { in clays on both } \\
\text { sides }\end{array}$ & $\begin{array}{l}\text { Bank slopes up to } 2 \mathrm{H}: 1 \mathrm{~V} 27^{\circ} \text { in } \\
\text { non-cohesive or unconsolidated } \\
\text { materials to } 0.8: 150^{\circ} \text { in clays on one or } \\
\text { occasionally both banks }\end{array}$ & $\begin{array}{l}\text { Bank slopes commonly steep; to } 1 \mathrm{H}: 1 \mathrm{~V} \\
45^{\circ} \text { in non-cohesive or unconsolidated } \\
\text { materials to } 0.6: 160^{\circ} \text { in clays common } \\
\text { on one or both banks }\end{array}$ & $\begin{array}{l}\text { Bank slopes consistently steep over } 45^{\circ} \\
\text { in non-cohesive or unconsolidated } \\
\text { materials or over } 60^{\circ} \text { in clays common } \\
\text { on one or both banks }\end{array}$ \\
\hline & $\begin{array}{l}\text { Upstream } \\
\text { Downstream }\end{array}$ & & & & \\
\hline \multirow[t]{2}{*}{ Vegetative bank protection [15] } & & $\begin{array}{l}\text { Primarily hard wood, leafy, deciduous trees with } \\
\text { mature, healthy, and diverse vegetation located on } \\
\text { the bank. Woody vegetation oriented vertically, } \\
\text { both banks are lined or heavily armored. }\end{array}$ & $\begin{array}{l}\text { Medium band of woody vegetation } \\
\text { with } 70-90 \% \text { plant density and cover. A } \\
\text { majority of hard wood, leafy, deciduous } \\
\text { trees with maturing, diverse vegetation } \\
\text { located on the bank. Woody vegetation } \\
\text { oriented } 80-90^{\circ} \text { from horizontal with } \\
\text { minimal root exposure. Partial lining or } \\
\text { armoring of one or both banks, } \\
\text { disturbed natural bank structure }\end{array}$ & $\begin{array}{l}\text { Small band of woody vegetation with } \\
50-70 \% \text { plant density and cover. A } \\
\text { majority of soft wood, piny, coniferous } \\
\text { trees with young or old vegetation } \\
\text { lacking in diversity located on or near } \\
\text { the top of bank. Woody vegetation } \\
\text { oriented at } 70-80^{\circ} \text { from horizontal often } \\
\text { with evident root exposure. No lining of } \\
\text { banks, but some armoring may be in } \\
\text { place on one bank; problems at present } \\
\text { bank protection }\end{array}$ & $\begin{array}{l}\text { Woody vegetation band may vary } \\
\text { depending on age and health with less } \\
\text { than } 50 \% \text { plant density and cover. } \\
\text { Primarily soft wood, piny, coniferous } \\
\text { trees with very young, old and dying, } \\
\text { and/or mono stand vegetation located } \\
\text { off of the bank. Woody vegetation } \\
\text { oriented at less than } 70^{\circ} \text { from horizontal } \\
\text { with extensive root exposure. No lining } \\
\text { or armoring of banks; serious at present } \\
\text { bank protection }\end{array}$ \\
\hline & $\begin{array}{l}\text { Upstream } \\
\text { Downstream }\end{array}$ & & & & \\
\hline \multirow{2}{*}{ Bank soil texture [15] } & & Clay and silty clay; cohesive material & Clay loam to sandy clay loam & Sandy clay to sandy loam & $\begin{array}{l}\text { Loamy sand to sand; non-cohesive } \\
\text { material }\end{array}$ \\
\hline & $\begin{array}{l}\text { Upstream } \\
\text { Downstream }\end{array}$ & & & & \\
\hline \multirow[t]{2}{*}{ Mass wasting or bank failure [15] } & & $\begin{array}{l}\text { No or little evidence of potential or very small } \\
\text { amounts of mass wasting; uniform channel width } \\
\text { over entire reach }\end{array}$ & $\begin{array}{l}\text { Evidence of infrequent and/or minor } \\
\text { mass wasting; mostly healed over with } \\
\text { vegetation; relatively constant channel } \\
\text { width and minimal scalloping of banks }\end{array}$ & $\begin{array}{l}\text { Evidence of frequent and/or significant } \\
\text { occurrences of mass wasting that can be } \\
\text { aggravated by higher flows, which may } \\
\text { cause under-cutting and mass wasting } \\
\text { of unstable banks; channel width quite } \\
\text { irregular and scalloping of banks is } \\
\text { evident }\end{array}$ & $\begin{array}{l}\text { Frequent and extensive mass wasting; } \\
\text { potential for bank failure, as evidenced } \\
\text { by tension cracks, massive } \\
\text { under-cuttings, and bank slumping, is } \\
\text { considerable; channel width is highly } \\
\text { irregular and banks are scalloped }\end{array}$ \\
\hline & $\begin{array}{l}\text { Upstream } \\
\text { Downstream }\end{array}$ & & & & \\
\hline \multirow[t]{3}{*}{ Bank cutting [15] } & & $\begin{array}{l}\text { Little or none evident. Infrequent raw banks less } \\
\text { than } 15 \mathrm{~cm} \text { high generally }\end{array}$ & $\begin{array}{l}\text { Some intermittently along channel } \\
\text { bends and at prominent constrictions. } \\
\text { Raw banks may be up to } 30 \mathrm{~cm}\end{array}$ & $\begin{array}{l}\text { Significant and frequent. Cuts } 30-60 \mathrm{~cm} \\
\text { high. Root mat overhangs }\end{array}$ & $\begin{array}{l}\text { Almost continuous cuts, some over } 60 \\
\mathrm{~cm} \text { high. Undercutting, sod-root } \\
\text { overhangs, and } \\
\text { side failures frequent }\end{array}$ \\
\hline & Upstream & & & & \\
\hline & Downstream & & & & \\
\hline
\end{tabular}


Table 6. Other effects.

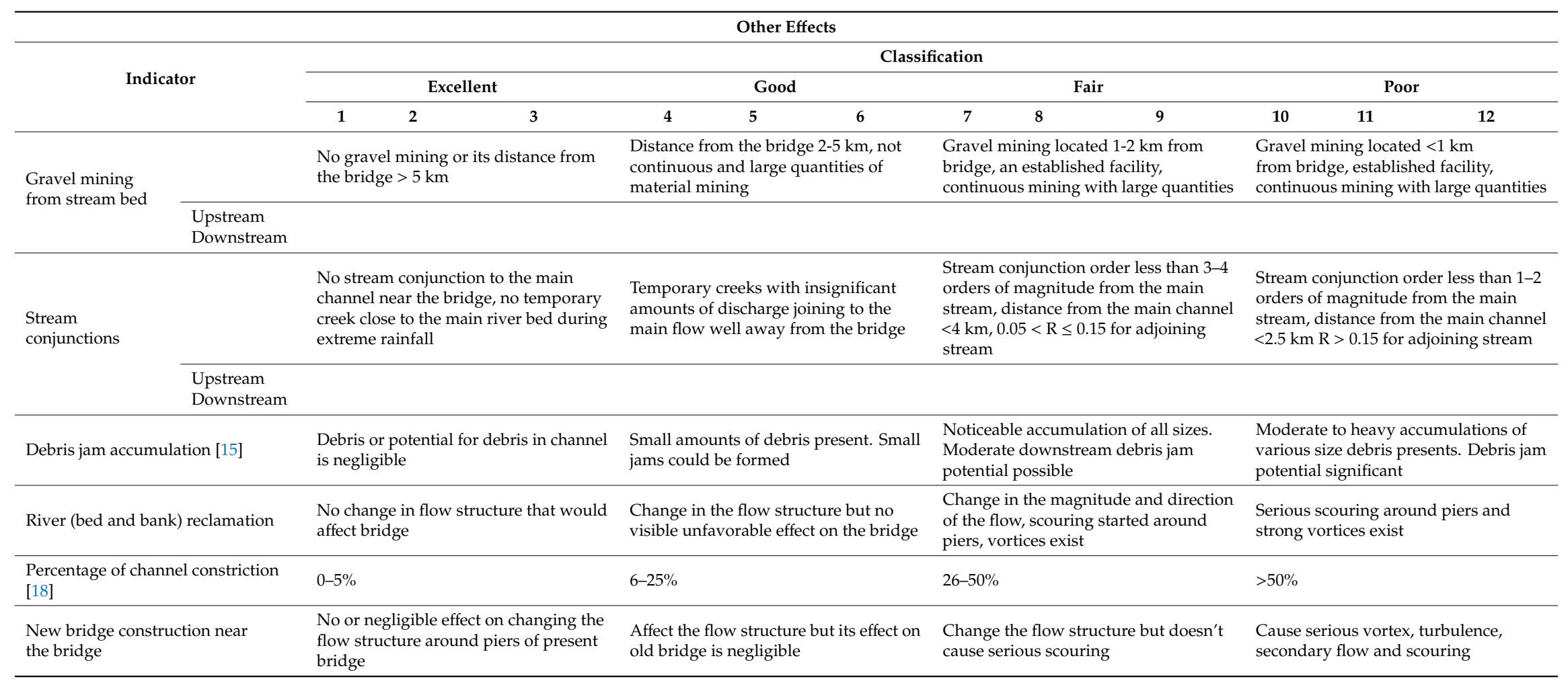


Another important factor was chosen-the stream conjunction, which affects bed slope of the main channel by carrying and accumulating significant amounts of sediment at those locations. Therefore, in the study, ruggedness number (R) described by Melton [43] was considered to describe the hydro-geomorphic process of floods to debris floods [44]. Another important indicator is debris accumulation at piers and in the openings of river bridges, which can easily be spotted during low flow seasons. During field trips, it was observed that accumulated debris, especially around piers, was not cleared causing an increase in scour hole depths. Another important issue was river reclamation, which is a common practice in the area due to frequent flood events in the basin. However, observations showed that it might change flow structure and cause channel migration in the vicinity of bridges. Hence, extra care should be given when a river bridge is involved in the process. During project duration, river reclamation was conducted near Gokcebey Bridge and it was seen that alignment of water was diverted to a pier. This is an important issue, since am increase in lateral channel migration after reclamation may accelerate the failure of river bridges, as stated by Johnson [27]. It was also observed that new bridges constructed near the old ones might cause increases in the local turbulence fields and scouring. Therefore, this was taken as an indicator in the developed method.

\subsection{Bridge Characteristics}

Some characteristics of river bridges may increase local scouring around foundations. As given in Table 7, bridge location, upstream distance to bridge from meander impact, bridge skewness, flow in the spans, and pier and abutment characteristics were selected as indicators of bridge characteristics. During inventory review and field studies, it was noted that location of bridges was an important common feature, besides distance of bridge site from a meander impact point and bridge skewness. A detailed review of the inventory of General Directorate of Highways showed that the skew angle of river bridges can increase up to $67^{\circ}$ due to topographic or economic constraints. Most of the known failed bridges were observed to have a skew angle of more than $10^{\circ}$. Among inspected bridges, Filyos V Bridge had a skew angle of $45^{\circ}$ while the skew angle of Bartin I Bridge was $20^{\circ}$. In an experimental study, Demir [45] showed that a bridge deck model with a skewness of $15^{\circ}$ increased the maximum depth of scour up to $57 \%$ under submerged flow conditions. Another important feature is the spans of the bridges that should be larger, and not constricted due to sediment deposition or debris accumulation, to let excessive water to pass through, especially during floods. Otherwise, submerged flow conditions, increased flow intensity and higher turbulence may result in excessive scouring around piers and the bridge may need to be closed to traffic for public safety resulting in additional operational and time costs. For instance, Bartin I Bridge was inundated during a 1998 flood event and the abutment of Gebelit Bridge failed in a 2013 flood event due to low meandering impact distance, bridge skewness and submerged flow conditions. Channel alignment, geometric characteristics and observability of piers, degree of scouring and existence of countermeasures around piers are also important indicators of stream stability and local scouring. Observability of bridge piers is also considered, since under water inspection it would be necessary to check the degree of scouring around piers. Moreover, inspection studies are easier around abutments in low flow seasons. However, in some cases, environmental factors affecting abutments and approach fill conditions should also be examined in terms of vulnerability of abutments with respect to erosion. 
Table 7. Bridge characteristics.

\begin{tabular}{|c|c|c|c|c|}
\hline \multirow{4}{*}{ Indicator } & \multicolumn{3}{|c|}{ Bridge Characteristics } & \\
\hline & \multicolumn{4}{|c|}{ Classification } \\
\hline & Excellent & Good & Fair & Poor \\
\hline & 3 & 6 & 9 & 12 \\
\hline Bridge location & At sea or lake level & On mild sloped streams & On valley streams & $\begin{array}{l}\text { On mountain skirts or steep } \\
\text { sloped streams }\end{array}$ \\
\hline $\begin{array}{l}\text { Upstream distance to bridge } \\
\text { from meander impact point } \\
\text { and alignment [27] }\end{array}$ & $\mathrm{D}_{\mathrm{m}}>35 \mathrm{~m}$ & $20<D_{m} \leq 35 m$ & $10<\mathrm{D}_{\mathrm{m}} \leq 20 \mathrm{~m}$ & $0<\mathrm{D}_{\mathrm{m}} \leq 10 \mathrm{~m}$ \\
\hline Bridge skewness [18] & $0 \leq \alpha \leq 5^{\circ}$ & $5<\alpha \leq 10^{\circ}$ & $10<\alpha \leq 30^{\circ}$ & $\alpha>30^{\circ}$ \\
\hline $\begin{array}{l}\text { Flow in the spans of } \\
\text { the bridge }\end{array}$ & $\begin{array}{l}\text { Sufficient opening, no backwater, free } \\
\text { surface flow present in the openings }\end{array}$ & $\begin{array}{c}\text { Sufficient opening, some backwater } \\
\text { building, free surface flow present in } \\
\text { the openings }\end{array}$ & $\begin{array}{l}\text { Water level rising to the bottom of the } \\
\text { bridge girder, pressurized flow exists }\end{array}$ & $\begin{array}{l}\text { Flow overflow the bridge at least one } \\
\text { time during its service life so weir type of } \\
\text { flow prevails }\end{array}$ \\
\hline \multicolumn{5}{|c|}{ Pier Characteristics } \\
\hline $\begin{array}{l}\text { Pier type, single or group of } \\
\text { piers and skew angle }\end{array}$ & $\begin{array}{l}\text { Single pier, rounded or semi-circular } \\
\text { nosed, no or negligible separation in } \\
\text { the flow }\end{array}$ & $\begin{array}{l}\text { Single pier, pier not rounded nosed in the } \\
\text { upstream or downstream side, separation } \\
\text { in the flow but not strong vortices }\end{array}$ & $\begin{array}{l}\text { Piers in tandem arrangement, no } \\
\text { skew angle, strong vortices exist }\end{array}$ & $\begin{array}{l}\text { Piers in tandem arrangement, skewness } \\
\text { and strong vortices exist }\end{array}$ \\
\hline Length width ratio & $<2$ & $2-3$ & $3-5$ & \multirow{2}{*}{$\begin{array}{c}>5 \\
\begin{array}{c}\text { Always under water so can never be } \\
\text { visually observed }\end{array}\end{array}$} \\
\hline Observability & Can always be observed & $\begin{array}{l}2-3 \\
\text { Can usually be observed due to the } \\
\text { shallowness of the water }\end{array}$ & $\begin{array}{l}\text { Can only be observed at dry season } \\
\text { when there is no stream flow }\end{array}$ & \\
\hline Scouring & $\begin{array}{l}\text { No or negligible depth of scouring } \\
\text { around piers, foundation wedges } \\
\text { not seen }\end{array}$ & $\begin{array}{l}\text { Little scouring, foundation wedges are } \\
\text { slightly seen }\end{array}$ & $\begin{array}{l}\text { Important amount of scouring where } \\
\text { foundation wedges can be seen }\end{array}$ & Serious amount of scouring around piers \\
\hline $\begin{array}{l}\text { Countermeasures } \\
\text { against scouring }\end{array}$ & \multirow[t]{2}{*}{$\begin{array}{l}\text { No need for any countermeasures } \\
\text { against scouring }\end{array}$} & $\begin{array}{l}\text { Large rocks are used against scouring, an } \\
\text { adequate and appropriate } \\
\text { countermeasure against scouring }\end{array}$ & $\begin{array}{c}\text { Large rocks are used against scouring } \\
\text { but they man adequate and } \\
\text { appropriate countermeasure against } \\
\text { scouring, rocks have been replaced } \\
\text { and countermeasure is not efficient }\end{array}$ & $\begin{array}{l}\text { Inappropriate or no countermeasure } \\
\text { taken against scouring }\end{array}$ \\
\hline \multicolumn{4}{|c|}{ Abutment Characteristics } & \\
\hline $\begin{array}{l}\text { Protection type and } \\
\text { conditions }\end{array}$ & $\begin{array}{l}\text { No damage in the reinforced concrete } \\
\text { shear wall, no deformation }\end{array}$ & $\begin{array}{l}\text { Small damage and cracks in the } \\
\text { reinforced concrete wall but no } \\
\text { deformation }\end{array}$ & $\begin{array}{l}\text { Cracks and damage in the reinforced } \\
\text { concrete shear wall, no deformation }\end{array}$ & $\begin{array}{l}\text { Serious cracks and damage in the } \\
\text { reinforced concrete shear wall and } \\
\text { deformation }\end{array}$ \\
\hline $\begin{array}{l}\text { Settlement and approach fill } \\
\text { condition }\end{array}$ & No visual settlement or deformation & $\begin{array}{l}\text { No visual settlement or deformation, } \\
\text { small amount of shear in the fill }\end{array}$ & $\begin{array}{l}\text { Serious shear and deformation in the } \\
\text { fill }\end{array}$ & $\begin{array}{l}\text { Settlement and serious shear in the fill, } \\
\text { fill wedge not functioning }\end{array}$ \\
\hline $\begin{array}{l}\text { Physical and environmental } \\
\text { factors affecting abutments }\end{array}$ & No change & $\begin{array}{l}\text { Little damage to the approach fill due to } \\
\text { road expansion }\end{array}$ & $\begin{array}{l}\text { Settlement occurred due to problems, } \\
\text { such as drainage or river reclamation }\end{array}$ & $\begin{array}{l}\text { Damaged by changing flow structure due } \\
\text { to river reclamation work etc. }\end{array}$ \\
\hline
\end{tabular}




\subsection{Rapid Procedure for Scour Check}

In addition to the hydrological and hydraulic evaluations, it is recommended to perform a rapid and simple scour check, specifically to detect any potential scouring problem at the foundations. Thus, river bridges that are not ranked as poor based on the developed method, but are still scour critical can be identified. The scour check involves information about foundations, the presence of any countermeasures against scouring, and characteristics of the river flow and bridge characteristics, such as skew angle, which directly increase scouring around infrastructural elements. Depending on the result of this assessment, a more detailed scour risk assessment could be advised in Level 2, including empirical equations $[46,47]$ and numerical model simulations to predict hydraulic conditions and sediment transport around piers and abutments. This level of assessment is recommended if the bridge is considered to be poor in Level 1, the basic assessment of the bridge.

\subsection{Structural Assessment of River Bridges}

Elements of river bridges should be inspected with regard to structural stability as well, every two years [48]. Berk [49] and Yanmaz et al. [50] noted the necessity of periodic inspections and effective factors on inspections and formed a structural checklist for river bridges in Turkey using sample bridges in USA and Turkey. That structural assessment was composed of main body, earth retaining and serviceability components of bridges. In this study, a ranking of the checklist for the structural evaluation of river bridges in Turkey proposed by Yanmaz et al. [50] was modified using the same classes as in hydraulic assessment. Tables 8 and 9 show the indicators of structural assessment and their classifications, respectively. Bridge characteristics specified in Tables 8 and 9 were obtained via visual inspection or from design projects of the bridges.

\subsection{Evaluation of Scoring of the Method}

Figure 2 illustrates the main steps of the developed safety-inspection algorithm. The method used for classification of the indicators was adopted from Johnson [27]. Each indicator of the watershed hydrology and flash flood potential, stream stability and bridge characteristics in the safety inspection algorithm was classified as excellent, good, fair and poor, and a rating value was assigned for that indicator ranging between 1 and 12. Johnson [27] noted that weighted indicators yielded the same results as the equally weighted indicators.

Therefore, in this study, each indicator in the method was also equally weighted as the rating value was determined. Then, a risk point (RP) was introduced in order to make a decision using the grading of the indicators. According to the adopted method, the initial value of the RP was set to zero and then for indicators classified as excellent or good, the value of RP did not change; while for indicators classified as fair, RP was increased by one; and for indicators classified as poor, RP was increased by two. Table 10 shows the change in RP with the grades of the indicators of hydrological and hydraulic assessment. The minimum and maximum values of HG changed between five and 60 , respectively, as seen in Table 2; and the ranges of HG were determined by dividing the highest possible difference in the grades of HG into four equal parts for the classification groups of excellent, good, fair and poor. Then, starting from five and taking excellent and good classes as one, since RP was not changed for those classes, the ranges of HG were determined. Thus, when all the indicators were classified as excellent or good, the RP would be zero, and if all the indicators were classified as poor, the RP would be 66, since there was a total of 33 indicators in the method (one for watershed hydrology, six for a stream bed, two for a floodplain, six for a stream bank, six for other effects and twelve for bridge characteristics). Then, the bridges were ranked according to the ranges of RP given in Table 11. The ranges of RP were determined by dividing the highest possible value of RP into three equal parts, each corresponding to the computation steps of RP: no change, increased by one and increased by two. The first part was then divided into two to determine the two-rating classification as excellent and good. This approach was adopted in the method, since the RP was not changed for indicators classified 
as excellent or good. A structural grade (SG) value, RP, was introduced and computed from the sum of $\mathrm{RV}$ of all indicators of structural assessment. According to the method, the SG was classified as given in Table 12 and the classification of its ranges was determined similarly to the RP. At the end of the assessment, a rapid scour assessment was carried out.

Table 8. Bridge characteristics.

\begin{tabular}{|c|c|c|c|}
\hline \multicolumn{4}{|c|}{ Components of Structural Assessment } \\
\hline \multicolumn{2}{|c|}{ Main Body Components } & \multicolumn{2}{|c|}{ Earth Retaining Components } \\
\hline \multirow[t]{5}{*}{ Deck } & Crack & Abutments & Deformation \\
\hline & Concrete disintegration & & Cracks \\
\hline & Apparent reinforcement & & Concrete Disintegration \\
\hline & Holes and cavities & & Apparent reinforcement \\
\hline & Water leakage & & Holes and cavities \\
\hline \multirow[t]{6}{*}{ Supports } & Main damage & & Water and debris abrasion \\
\hline & Support bed & & Scour in foundation \\
\hline & Loss of elements & & Settlement and slump \\
\hline & Anchorage & Approach fill & Erosion on road platform \\
\hline & Surface arrangement & & Erosion in fill \\
\hline & Deformation & & Settlement and slump \\
\hline \multirow[t]{7}{*}{ Beams } & Deformation & Stabilization & Erosion \\
\hline & Cracks & & Scour in bed level \\
\hline & Rusting & Serviceability Components & \\
\hline & Bolts and rivets & Coating & Waving \\
\hline & Concrete Disintegration & & Tire tracks \\
\hline & Apparent reinforcement & & Cracks \\
\hline & Holes and cavities & & Holes and cavities \\
\hline \multirow[t]{12}{*}{ Piers } & Deformation & Border & Cracks \\
\hline & Cracks & & Concrete disintegration \\
\hline & Concrete Disintegration & & Apparent reinforcement \\
\hline & Apparent reinforcement & Railing & Deformation \\
\hline & Holes and cavities & & Rusting \\
\hline & Water and debris abrasion & & Deficiency \\
\hline & Scour in foundation & Expansion joint & Noise \\
\hline & & & Water leakage \\
\hline & & & Deformation \\
\hline & & & Holes and cavities \\
\hline & & & Loss of elements \\
\hline & & & Loss of function \\
\hline
\end{tabular}

Table 9. Bridge characteristics.

\begin{tabular}{|c|c|c|c|c|c|c|c|c|c|c|c|}
\hline \multicolumn{12}{|c|}{ Structural Components } \\
\hline \multirow{3}{*}{ Indicator } & \multicolumn{11}{|c|}{ Classification } \\
\hline & \multicolumn{2}{|c|}{ Excellent } & \multicolumn{3}{|c|}{ Good } & \multicolumn{3}{|c|}{ Fair } & \multicolumn{3}{|c|}{ Poor } \\
\hline & 1 & 3 & 4 & 5 & 6 & 7 & 8 & 9 & 10 & 11 & 12 \\
\hline $\begin{array}{l}\text { Listed in } \\
\text { Table } 8\end{array}$ & \multicolumn{2}{|c|}{$\begin{array}{l}\text { New or undamaged, } \\
\text { damaged or } \\
\text { deterioration is yet in } \\
\text { its early stages }\end{array}$} & \multicolumn{3}{|c|}{$\begin{array}{l}\text { Slightly damaged but } \\
\text { noticeable, causing } \\
\text { no problem }\end{array}$} & \multicolumn{3}{|c|}{$\begin{array}{l}\text { Damaged but still } \\
\text { functioning, stability } \\
\text { problem has started } \\
\text { to occur }\end{array}$} & \multicolumn{3}{|c|}{$\begin{array}{l}\text { Severely damaged, serious } \\
\text { safety problems, urgent } \\
\text { action needed, element } \\
\text { deficiency or cannot } \\
\text { be assessed }\end{array}$} \\
\hline
\end{tabular}




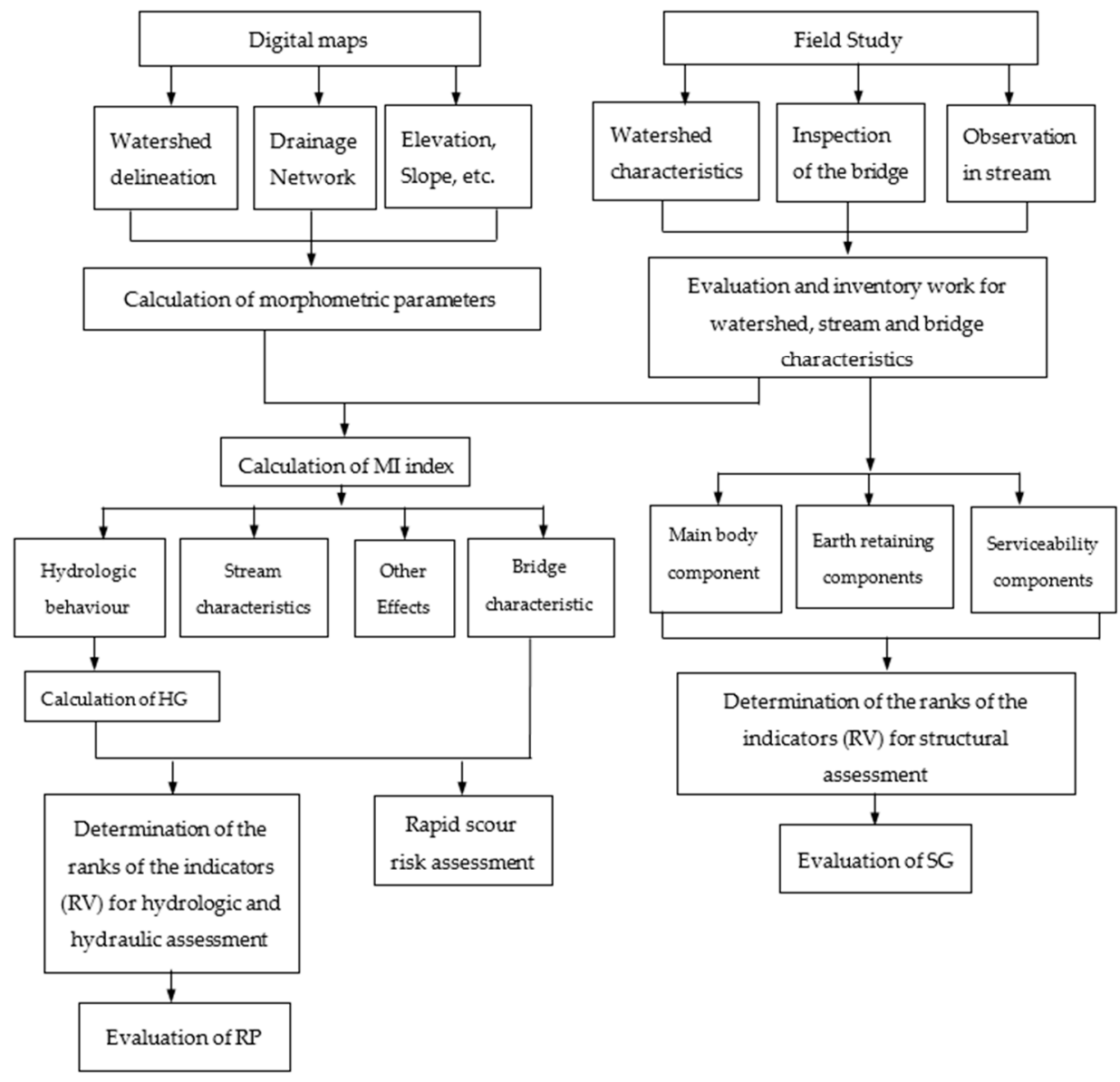

Figure 2. Schematic of developed safety-inspection methodology.

Table 10. Determination of risk point (RP) value using hydrological grade (HG) and ranking values (RV).

\begin{tabular}{cccc}
\hline Header & RP Not Changed & RP Increased by $\mathbf{1}$ & RP Increased by 2 \\
\hline Hydrologic evaluation & $\mathrm{HG}<33$ & $33 \leq \mathrm{HG}<47$ & $\mathrm{HG} \geq 47$ \\
Hydraulic evaluation & $1<\mathrm{RV}<7$ & $7 \leq \mathrm{RV} \leq 9$ & $10 \leq \mathrm{RV} \leq 12$ \\
\hline
\end{tabular}

Table 11. Evaluation of river bridges in terms of RP.

\begin{tabular}{|c|c|c|c|}
\hline Case & $\mathbf{R P}$ & Rating & Recommended Action against Hydraulic Factors \\
\hline 1 & $0 \leq R P \leq 11$ & Excellent & No significant hydraulic factors acting on the bridge. \\
\hline 2 & $11<\mathrm{RP} \leq 22$ & Good & $\begin{array}{l}\text { There are hydraulic factors affecting the bridge but } \\
\text { no problem on the bridge. }\end{array}$ \\
\hline 3 & $22<\mathrm{RP} \leq 44$ & Fair & $\begin{array}{l}\text { Important hydraulic factors affecting the bridge. } \\
\text { Precautions should be taken and the bridge } \\
\text { be monitored }\end{array}$ \\
\hline 4 & $\mathrm{RP}>44$ & Poor & $\begin{array}{l}\text { Very important hydraulic factors affecting the bridge. } \\
\text { Urgent action should be taken. Level } 2 \text { Works should } \\
\text { be carried out. }\end{array}$ \\
\hline
\end{tabular}


Table 12. Evaluation of river bridges in terms of structure grade (SG).

\begin{tabular}{|c|c|c|c|}
\hline Case & SG & Rating & Recommended Action against Structural Condition \\
\hline 1 & SG $<199$ & Excellent & No maintenance-repair is needed. \\
\hline 2 & $199 \leq \mathrm{SG}<345$ & Good & Minor maintenance-repair work present but not urgent. \\
\hline 3 & $345 \leq \mathrm{SG}<491$ & Fair & $\begin{array}{l}\text { Maintenance-repair is needed. Bridge must be } \\
\text { regularly inspected. }\end{array}$ \\
\hline 4 & $\mathrm{SG} \geq 491$ & Poor & $\begin{array}{l}\text { Urgent maintenance-repair is needed. Bridge has } \\
\text { structural problems. }\end{array}$ \\
\hline
\end{tabular}

\section{Results and Discussion}

Five river bridges located in the Western Black Sea Basin were selected for detailed inspection and the application of the proposed method. Results of ratings of those bridges with regard to hydrological and hydraulic bridge characteristics are given in Table 13. Starting from zero, the RP value was determined, as given in Table 13, for both hydrological and hydraulic evaluation. In the table, the overall score of hydrological evaluation HG was obtained using Table 2 and was classified as given in Table 9. Furthermore, for each bridge the single underlined RVs in the column increased RP by one while double underlined ones increased RP by two. For structural assessment, the RV of each indicator in the same column presented in Table 14 was simply summed up to obtain SG values for each bridge. Table 15 shows the HG, RP and SG values of those bridges inspected and Table 16 gives the grading of the bridges with regard to hydrological, hydraulic and structural indicators. Finally, a rapid scour assessment was performed as given in Table 17.

As seen from Table 15, the most critical river bridge was determined to be the Filyos V Bridge, while Bartin III was found to be the least critical, based on hydraulic assessment. In order to interpret the results and evaluate the capability of the method, available inventory of those inspected bridges was examined. It was found that Filyos V Bridge was repaired after a 1998 flood event due to a settlement of $65 \mathrm{~cm}$ at one of its piers, and since then the bridge was kept under regular inspection due to the persistence of the problem. After some maintenance work for the solution, the 15th Regional Directorate of GDH, the local bridge owner, decided to demolish the bridge. However, the bridge is currently in service due to the lack of alternative routes. Therefore, possible alternatives are being considered for the solution. Contrarily, Bartin III Bridge, which was determined as the least critical with respect to hydraulic assessment, has not ever been submerged or closed to traffic in its service life even during the catastrophic flood of 1998, which affected Bartin I Bridge and many others in the area. The rest of the inspected bridges were ranked "fair," as given in Table 16.

Another example for effective hydraulic factors was Gokcebey Bridge, which had a crack at its abutment and experienced serious maintenance in 1968. Then, again in 1999, it was reconditioned after a progressive settlement at one of its abutments. Repeating similar problems at those bridges show the importance of detecting problems caused by hydraulic factors, since the condition is persistent and only defining the source of the problem can enable an appropriate solution. When the results of the application of the method were analyzed, it was found that the bridges having problems due to hydraulic factors were successfully identified. Moreover, further assessment for Filyos V Bridge was strongly recommended according to the rapid scour assessment, while scouring around piers of other bridges was considered negligible, as presented in Table 17. It was also seen that there was a good agreement between the results of the proposed method and the rapid scour assessment, showing that indicators of hydraulic factors affecting scouring around piers were successfully identified and ranked. 
Table 13. Grading of river bridges in regard to hydraulic indicators.

\begin{tabular}{|c|c|c|c|c|c|c|}
\hline Components & Indicators & Bartin I & Bartin III & Catalzeytin & Filyos V & Gokcebey \\
\hline $\begin{array}{l}\text { Hydrologic } \\
\text { evaluation }\end{array}$ & Overall score & 48 & 49 & 52 & 45 & 46 \\
\hline \multirow{6}{*}{$\begin{array}{c}\text { Stream bed } \\
\text { characteristics }\end{array}$} & Flow habit & 5 & 6 & 7 & 9 & 9 \\
\hline & Stream longitudinal profile & 8 & 7 & 11 & 9 & 7 \\
\hline & Channel pattern & 7 & 6 & 9 & 11 & 9 \\
\hline & Bed material & 5 & 5 & 3 & 5 & 6 \\
\hline & Channel bed protection, consolidation and armoring & 4 & 1 & 9 & 5 & 7 \\
\hline & Bar development, material and plant cover characteristics & 1 & 1 & 10 & 12 & 8 \\
\hline \multirow{2}{*}{$\begin{array}{c}\text { Floodplain } \\
\text { characteristics }\end{array}$} & Floodplain formation & 12 & 12 & 12 & 12 & 12 \\
\hline & Floodplain width and cover & 12 & 10 & 12 & 7 & 5 \\
\hline \multirow{6}{*}{$\begin{array}{c}\text { Bank } \\
\text { Characteristics }\end{array}$} & Bank height & 9 & 5 & 5 & 12 & 3 \\
\hline & Average bank slope angle & 10 & 8 & 12 & 11 & 9 \\
\hline & Vegetative bank protection & 1 & 6 & 1 & 8 & 3 \\
\hline & Bank soil texture & 8 & 1 & 1 & 12 & 1 \\
\hline & Mass wasting or bank failure & 6 & 6 & 1 & 4 & 1 \\
\hline & Bank cutting & 3 & 2 & 1 & 3 & 1 \\
\hline \multirow[t]{6}{*}{ Other Effects } & Gravel mining from stream bed & 1 & 1 & 1 & 1 & 8 \\
\hline & Stream conjunctions & 8 & 12 & 12 & 7 & 10 \\
\hline & Debris jam accumulation & 9 & 10 & 3 & 12 & 9 \\
\hline & River (bed and bank) reclamation & 1 & 3 & 7 & 5 & 9 \\
\hline & Percentage of channel constriction & 4 & 2 & 1 & 2 & 1 \\
\hline & New bridge construction near the bridge & 1 & 8 & 1 & 1 & 1 \\
\hline \multirow{12}{*}{$\begin{array}{c}\text { Bridge } \\
\text { Characteristics }\end{array}$} & Bridge location & 4 & 4 & 3 & 8 & 4 \\
\hline & $\begin{array}{l}\text { Upstream distance to bridge from meander impact point } \\
\text { and alignment }\end{array}$ & 4 & 6 & 1 & 2 & 9 \\
\hline & Bridge skewness & 8 & 1 & 1 & 12 & 1 \\
\hline & Flow in the spans of the bridge & 12 & 9 & 3 & 4 & 3 \\
\hline & Pier type, single or group of piers and skew angle & 7 & 7 & 5 & 10 & 2 \\
\hline & Pier length width ratio & 2 & 2 & 11 & 2 & 12 \\
\hline & Pier Observability & 12 & 12 & 9 & 12 & 10 \\
\hline & Scouring in piers & 5 & 5 & 7 & 8 & 9 \\
\hline & Countermeasures against scouring (pier) & 12 & 7 & 11 & 9 & 11 \\
\hline & Protection type and conditions (abutment) & 11 & 11 & 9 & 12 & 3 \\
\hline & Settlement and approach fill condition & 10 & 11 & 6 & 12 & 3 \\
\hline & Physical and environmental factors affecting abutments & 1 & 1 & 1 & 7 & 7 \\
\hline
\end{tabular}

According to the structural assessment, the most critical bridge was found to be Bartin III Bridge (Tables 15 and 16). During visual inspections, serious structural problems, such as segregation, deterioration of concrete cover leading to corrosion of reinforcements, and cavities on the concrete surface at the bridge were observed. Bartin III Bridge got the highest SG value from the inspection. Therefore, the safety-inspection method classified the bridge as structurally poor. Hence, it was recommended that Bartin III Bridge should urgently be inspected with equipment and necessary maintenance should be carried out.

Considering the current situation of Filyos V Bridge, some amendments could be suggested with simple or comprehensive measures that can be made on the auxiliary elements of the bridge, which was classified as the poorest bridge among four other bridges. Generally speaking, scour holes observed at the piers were assumed to be partly induced by debris accumulation, such as tree branches and trunks. A simple scaled rod can be installed at scour critical piers of the bridges, thus scour depth around piers can be observed. It should be noted that important bridges crossing large rivers may be supplemented by a sonar instrument for continuous monitoring of scour patterns. Sufficient quantities of riprap can also be dumped into scour holes to mitigate further scouring around piers of the bridge. Damages to the guiding wall of abutments and approach fill should be repaired. That way, a reduction in the RP of the bridge by 11 points can be achieved. Thus, instead of a costly solution, such as reconstruction of a new bridge, the risk factors can be reduced by repairing the problematic parts. Moreover, construction of a new bridge without considering the stream stability and other local hydraulic indicators may result in the same problems in time. Therefore, inventory of those bridges and lessons learned can be used during design stage of new bridges nearby. Furthermore, HYRISK [51], a risk-based software can be applied to determine the annual risk of scour to a bridge, as done by Yanmaz and Apaydin [52] for several bridges in Turkey. 
Table 14. Grading of river bridges with regard to structural indicators.

\begin{tabular}{|c|c|c|c|c|c|c|}
\hline Components & Indicators & Bartin I & Bartin III & Catalzeytin & Filyos V & Gokcebey \\
\hline \multirow{5}{*}{ Deck } & Cracks & 3 & 12 & 2 & 2 & 3 \\
\hline & Concrete Disintegration & 6 & 12 & 7 & 7 & 6 \\
\hline & Apparent reinforcement & 8 & 12 & 7 & 7 & 7 \\
\hline & Holes and cavities & 6 & 12 & 7 & 5 & 3 \\
\hline & Water leakage & 10 & 12 & 8 & 11 & 5 \\
\hline \multirow{6}{*}{ Support } & Main damage & 12 & 12 & 12 & 12 & 12 \\
\hline & Support bed & 12 & 12 & 12 & 12 & 12 \\
\hline & Loss of elements (M) & 12 & 12 & 12 & 12 & 12 \\
\hline & Anchorage (M) & 12 & 12 & 12 & 12 & 12 \\
\hline & Surface arrangement (E) & - & - & - & - & - \\
\hline & Deformation (E) & - & - & - & - & - \\
\hline \multirow{8}{*}{ Beams } & Deformation & 12 & 12 & 12 & 12 & 12 \\
\hline & Cracks & 2 & 7 & 2 & 2 & 6 \\
\hline & Rusting (S) & - & - & - & - & - \\
\hline & Bolts and rivets (S) & - & - & - & - & - \\
\hline & Welding (S) & - & - & - & - & - \\
\hline & Concrete Disintegration (C) & 10 & 12 & 7 & 7 & 7 \\
\hline & Apparent reinforcement $(\mathrm{C})$ & 10 & 12 & 8 & 7 & 7 \\
\hline & Holes and cavities (C) & 8 & 12 & 6 & 2 & 4 \\
\hline \multirow{7}{*}{ Piers } & Deformation & 12 & 12 & 12 & 12 & 12 \\
\hline & Cracks & 3 & 2 & 2 & 2 & 2 \\
\hline & Concrete Disintegration & 12 & 12 & 7 & 4 & 7 \\
\hline & Apparent reinforcement & 2 & 12 & 7 & 2 & 8 \\
\hline & Holes and cavities & 10 & 12 & 6 & 2 & 6 \\
\hline & Water and debris abrasion & 7 & 11 & 11 & 12 & 9 \\
\hline & Scour in foundation & 12 & 12 & 8 & 12 & 12 \\
\hline \multirow{7}{*}{ Abutments } & Deformation & 12 & 12 & 12 & 12 & 12 \\
\hline & Cracks & 2 & 1 & 1 & 3 & 1 \\
\hline & Concrete Disintegration & 1 & 1 & 1 & 3 & 1 \\
\hline & Apparent reinforcement & 1 & 1 & 1 & 1 & 1 \\
\hline & Holes and cavities & 1 & 1 & 1 & 1 & 1 \\
\hline & Water and debris abrasion & 1 & 1 & 1 & 1 & 1 \\
\hline & Scour in foundation & 1 & 1 & 1 & 1 & 1 \\
\hline \multirow{3}{*}{ Approach fill } & Settlement and slump & 5 & 9 & 11 & 10 & 2 \\
\hline & Erosion on road platform & 3 & 8 & 11 & 7 & 1 \\
\hline & Erosion in fill & 1 & 6 & 11 & 12 & 2 \\
\hline \multirow{3}{*}{ Stabilization } & Settlement and slump & 11 & 11 & 1 & 11 & 1 \\
\hline & Erosion & 11 & 11 & 1 & 11 & 1 \\
\hline & Scour in bed level & 11 & 11 & 1 & 11 & 1 \\
\hline \multirow{4}{*}{ Coating } & Waving & 6 & 7 & 12 & 10 & 8 \\
\hline & Tire tracks & 8 & 8 & 12 & 9 & 7 \\
\hline & Cracks & 5 & 7 & 8 & 9 & 6 \\
\hline & Holes and cavities & 3 & 5 & 7 & 8 & 4 \\
\hline \multirow{3}{*}{ Border } & Cracks (C) & 6 & 7 & 4 & 6 & 2 \\
\hline & Disintegration $(\mathrm{C})$ & 5 & 12 & 8 & 10 & 4 \\
\hline & Apparent reinforcement (C) & 4 & 12 & 6 & 8 & 2 \\
\hline \multirow{3}{*}{ Railings } & Deformation & 6 & 5 & 11 & 10 & 2 \\
\hline & Rusting (S) & 7 & 7 & 10 & 8 & 5 \\
\hline & Deficiency (S) & 2 & 6 & 10 & 6 & 2 \\
\hline \multirow{6}{*}{ Expansion joint } & Noise & 9 & 12 & 12 & 12 & 10 \\
\hline & Water leakage & 9 & 12 & 12 & 12 & 12 \\
\hline & Deformation & 12 & 12 & 12 & 12 & 12 \\
\hline & Holes and cavities & 12 & 12 & 12 & 12 & 12 \\
\hline & Loss of elements & 12 & 12 & 12 & 12 & 12 \\
\hline & Loss of function & 12 & 12 & 12 & 12 & 12 \\
\hline \multirow{3}{*}{ Drainage } & Pipe damage & 10 & 11 & 11 & 10 & 8 \\
\hline & Blockage & 12 & 12 & 12 & 11 & 8 \\
\hline & Cleanout & 12 & 12 & 12 & 11 & 11 \\
\hline
\end{tabular}

${ }^{*}$ M: Metallic; E: Elastomeric; S: Steel; C: Concrete. 
Table 15. Inspection grades for river bridges.

\begin{tabular}{cccc}
\hline Bridge Name & Hydrologic Grade (HG) & $\begin{array}{c}\text { Hydrologic and Hydraulic } \\
\text { Assessment (RP) }\end{array}$ & $\begin{array}{c}\text { Structural } \\
\text { Assessment (SG) }\end{array}$ \\
\hline Bartin I & 48 & 26 & 394 \\
Bartin III & 49 & 22 & 493 \\
Catalzeytin & 52 & 25 & 416 \\
Filyos V & 45 & 34 & 428 \\
Gokcebey & 46 & 23 & 329 \\
\hline
\end{tabular}

Table 16. Prioritization of river bridges according to inspection grades.

\begin{tabular}{ccccc}
\hline No & Hydraulic Assessment & Bridge Rating & Structural Assessment & Bridge Rating \\
\hline 1 & Filyos V & Fair & Bartin III & Poor \\
2 & Bartin I & Fair & Filyos V & Fair \\
3 & Catalzeytin & Fair & Catalzeytin & Fair \\
4 & Gokcebey & Fair & Bartin I & Fair \\
5 & Bartin III & Good & Gokcebey & Good \\
\hline
\end{tabular}

Table 17. Rapid scour assessment for river bridges.

\begin{tabular}{|c|c|c|c|c|c|}
\hline Indicator & Bartin I & Bartin III & Catalzeytin & Filyos V & Gokcebey \\
\hline Foundation on sound ground? & No & No & No & No & No \\
\hline $\begin{array}{l}\text { Adequate and appropriate } \\
\text { precautions against scouring? }\end{array}$ & No & Yes & Yes & No & Yes \\
\hline $\begin{array}{l}\text { River flow high and fast, } \\
\text { unsteady? }\end{array}$ & No & & & Yes & \\
\hline Instability in river bed? & & & & Yes & \\
\hline $\begin{array}{l}\text { Bridge immediately downstream } \\
\text { of a bend or skewness }>10^{\circ} ?\end{array}$ & & & & Yes & \\
\hline Decision & $\begin{array}{l}\text { Negligible } \\
\text { scouring } \\
\text { problem }\end{array}$ & $\begin{array}{l}\text { Negligible } \\
\text { scouring } \\
\text { problem }\end{array}$ & $\begin{array}{l}\text { Negligible } \\
\text { scouring } \\
\text { problem }\end{array}$ & $\begin{array}{l}\text { Proceed } \\
\text { to Level } 2 \\
\text { assessment }\end{array}$ & $\begin{array}{c}\text { Negligible } \\
\text { scouring } \\
\text { problem }\end{array}$ \\
\hline
\end{tabular}

Age of the bridge is an important indicator for hydraulic/hydrologic and structural aspects. The effect of the age is implicitly considered in this study for structural evaluation of bridge components. Based on in-situ observations and some tests, e.g., aiming to detect the instantaneous compressive strength of concrete, the aging effect can be considered. Using such information, the approximate remaining lifetime of the bridge concerned can be estimated. Caner et al. [48] developed a simple method to assess the remaining service life of a bridge through defining a relationship between its current condition rating and its age by evaluating a set of bridges of different ages in Turkey. With the integration of this method, more realistic grading can be handled for structural components of bridges. The age of the bridge can also be considered for a more comprehensive analysis of the scouring history. However, with no field data reflecting scour hole geometries belonging to individual past storms, a realistic analysis of the effects of past storms on bridge scouring cannot be handled. Even limited scour data are available for some bridges; accuracy of the data is highly questionable, since it is almost impossible to gather scour data during the period of maximum flows. When the scour depths are measured after the flood wave leaves the bridge section, the scour hole might have been filled with the sediment accumulated during the falling stage of the flood or debris accumulation. Therefore, maximum scour depth data are not available. Furthermore, even if highly sophisticated sonar sensors are installed on bridge piers for continuous monitoring of the streambed, they may be swept away by the high impact effect of flood wave. Therefore, the valuable information will be lost. On the other hand, it is a regular approach by the GDH to fill the scour holes around piers and abutments of 
bridges with riprap after heavy floods. Carrying that out would certainly affect local turbulent flow field, hence the bed regime. As a concluding remark, although past flow data may be available, the corresponding conditions at bridge sites are definitely unknown. This makes it impossible to attain a reliable scouring history for a bridge. Moreover, it should be kept in mind that the proposed inspection check is based on instantaneous field observations reflecting the date of visit at several seasons to consider the effect of variations in flow conditions. With the detailed studies concerning evaluations of geomorphic variables and hydrological information, more realistic information can be obtained for flood characteristics, which would definitely characterize the type and depth of scour hole, to be used in Level 2 analysis.

When the proposed algorithm is accepted to be used as an integral component of the BMS by GDH, bridges will be assigned a kind of identity card. With the implementation and use of the proposed algorithm, which is partly based on in-situ observations and hydrological evaluations, it will eventually be possible to rank the bridges according to priorities in regard to repair and maintenance needs. With the collected future information and its interpretation, more robust validation would be achieved for those bridges, which were identified as critical ones.

Globally, there are numerous BMSs, ranging from very sophisticated ones with detailed measurements and advanced decision-making systems, to very simple ones with only basic visual inspections. Features of the BMS depend on the characteristics of the bridge stock, the need and future projections of the country and its budget. For instance, Pontis is used in the USA [53] with a well-developed and comprehensive database; namely, the National Bridge Inventory. The UK, which has one of the oldest infrastructural systems in the world does not have a national BMS. It has a Structures Information Management System, two manuals for design, assessment and operation, with one manual for guidance on scouring on infrastructure. On the other hand, some countries, such as Belgium, France, Germany and Ireland use engineering judgement for decision-making instead of a BMS [7]. In the BMS introduced in Turkey in 2017, the hydrological and hydraulic factors were not sufficiently considered for river bridges. Therefore, the developed-safety inspection method that could be implemented into the BMS would enable a comprehensive database for river bridges considering the work load and budget limits of the GDH.

\section{Conclusions}

In this study, a safety-inspection method was developed for river bridges in Turkey. The method specifically takes into account the effects of hydraulic factors on river bridges. The Western Black Sea Basin, Turkey, was selected as the study area, where incidents of severe damage or failure of river bridges frequently occur. Inspection methodology consists of watershed hydrology and flash flood potential, and stream and bridge characteristics, with a rapid and simple scour assessment. Most of the indicators about stream stability were taken from Johnson [17], lessons learned from past failures of river bridges and observations from field studies. Due to the absence of required data for calibration of the classification of the indicators and the method, five river bridges in the study area were chosen for detailed inspection and observation. Results of hydraulic assessment showed that Filyos V Bridge was ranked as fair, with the highest rating score among the sample, while Bartin III Bridge was good and the rest were classified as fair. Inventory of the bridge also proved that serious problems due to hydraulic factors were encountered and demolishing of the bridge was an option. A rapid scour assessment also recommended that Filyos V Bridge was a scour-critical river bridge and further studies should be undertaken. Although Filyos V and Gokcebey Bridges were on the same watercourse and close to each other, Filyos V Bridge was found to be more critical. This might show the importance of bridge characteristics that were taken into consideration. It was also noted that gravel mining was a serious problem in the area. This was a threat, especially for Gokcebey Bridge, downstream of which is a nearby runoff river plant. During the three-year inspection period, debris at the piers was not removed and found to create a serious problem for increasing scouring potential around the piers. 
Bartin III Bridge was found to be subject to structural deficiencies of main body components. Therefore, retrofitting of the bridge should be performed.

It should be noted herein that the calibration of the classification limits of the indicators and the method could be performed with the collection of necessary input data from numerous river bridges over time, thus the capability of the developed algorithm could be improved. With the help of the developed safety-inspection method, the management and maintenance of river bridges in Turkey could be improved, and necessary maintenance work could be scheduled according to the RP values of the bridges. Thus, the lifespan and the serviceability of the bridges could be extended. Furthermore, new bridges that could be exposed to increased flood potential can be designed accordingly. A failure risk assessment using those indicators as inputs of channel, substructure and scour criticality conditions, can also be estimated. Developed by considering hydrological, hydraulic and management conditions in Turkey, this method can be recommended for use in countries with no detailed safety-inspection methodology.

Author Contributions: A.M.Y. and M.B.K. designed the research and methodology; M.B.K. and H.A. conducted the field studies; A.M.Y., M.B.K. and H.A. analyzed the data and developed the model; A.M.Y., M.B.K. and H.A designed and wrote the paper.

Funding: This research was funded by the TÜRKIYYE BILIMSEL VE TEKNOLOJIK ARAŞTIRMA KURUMU, grant number 114M292.

Conflicts of Interest: The authors declare no conflict of interest.

\section{Abbreviations}

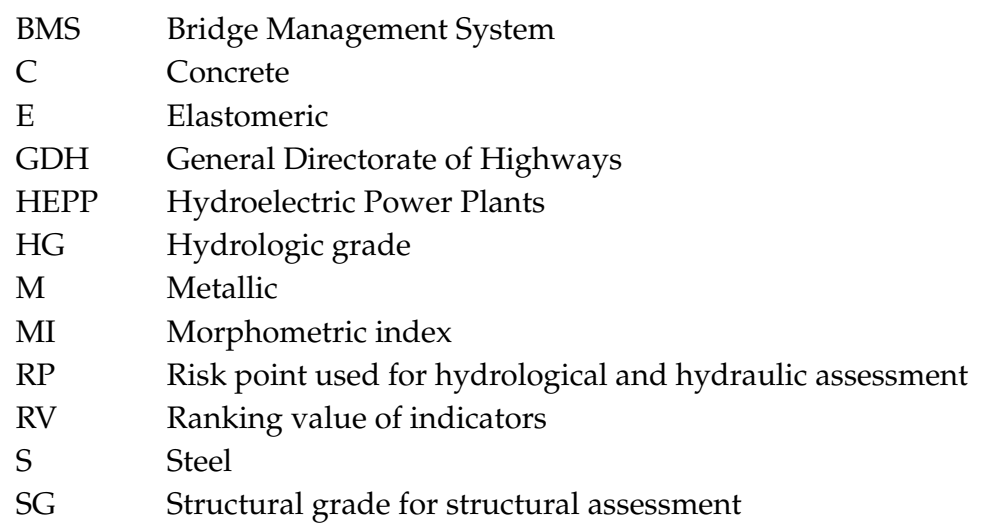

\section{References}

1. Yanmaz, A.M.; Baduna Kocyigit, M.; Kocyigit, O.; Seker, N.; Akay, H.; Yilmaz, M. Final Report of Safety-Inspection Methodology and Scour Risk Assessment for River Bridges in Turkey; Kastamonu Case Study; TUBITAK: Ankara, Turkey, 2018. (In Turkish)

2. Akay, H. Development of Safety-Inspection Methodology for River Bridges in Turkey. Ph.D. Thesis, Gazi University, Ankara, Turkey, 2018. (In Turkish).

3. Lipkus, S.E. Bridgit Bridge Management System Software; TRB Circular No. 423; Transportation Research Board: Washington, DC, USA, 1994.

4. $\quad$ Lauridsen, J.; Bjerrum, J.; Andersen, N.H.; Lassen, B. Creating a Bridge Management System. Struct. Eng. Int. 1998, 8, 216-220. [CrossRef]

5. Soederqvist, M.K.; Veijola, M. The Finnish Practice and Experience Regarding Bridge Inspection and Management. Struct. Eng. Int. 1998, 8, 315-319.

6. Thompson, P.D.; Small, E.; Johnson, M.; Marshall, A.R. The Pontis Bridge Management System. Struct. Eng. Int. 1993, 8, 303-308. [CrossRef] 
7. Pregnolato, M. Bridge Safety is Not for Granted-A Novel Approach to Bridge Management. Eng. Struct. 2019, 196, 109193. [CrossRef]

8. Orcesi, A.D.; Cremona, C.F. Optimization of Maintenance Strategies for the Management of the National Bridge Stock in France. Bridge Eng. 2011, 16, 44-52. [CrossRef]

9. Calabrese, C. Ponti e Cavalcavia, Proposto un Database 'Open' per Monitorarli. Edilportale Sicurezza. 2017. Available online: https://goo.gl/Y1uAgS (accessed on 30 May 2017).

10. Business Standard. Road Ministry to Compile Database of All Bridges on Highways in India. Business Standard, 2016. Available online: https://goo.gl/xujEZn (accessed on 19 September 2016).

11. Mirzaei, Z.; Adey, B.T.; Thompson, P.; Klatter, L. The IABMAS Bridge Management Committee Overview of Existing Bridge Management Systems, Report by the IAMBAS Bridge Management Committee. In Proceedings of the International Association for Bridge Maintenance and Safety (IABMAS), Shanghai, China, 7-11 July 2014.

12. Nasr, A.; Björnsson, I.; Honfi, D.; Ivanov, O.L.; Johansson, J.; Kjellström, E. A Review of the Potential Impacts of Climate Change on the Safety and Performance of Bridges. Sustain. Resilient Infrastruct. 2019. [CrossRef]

13. Jongman, B.; Hochrainer-Stigler, S.; Feyen, L.; Aerts, J.C.J.H.; Mechler, R.; Botzen, W.J.W.; Bouwer, L.M.; Pflug, G.; Rojas, R.; Ward, P.J. Increasing Stress on Disaster Risk Finance Due to Large Floods. Nat. Clim. Chang. 2014, 4, 264-268. [CrossRef]

14. Khelifa, A.; Garrow, L.A.; Higgins, M.J.; Meyer, M.D. Impacts of Climate Change on Scour-Vulnerable Bridges: Assessment Based on HYRISK. J. Infrastruct. Syst. 2013, 19, 138-146. [CrossRef]

15. Pfankuch, D.J. Stream Reach Inventory and Channel Stability Evaluation; Forest Service, Northern Region U.S. Dept. of Agriculture: Missoula, MT, USA, 1979.

16. Mitchell, P. The Environmental Condition of Victorian Streams; Department of Water Resources Victoria: Melbourne, Australia, 1990; ISBN 072417267X.

17. Gordon, N.D.; McMahon, T.A.; Finlayson, B.L. Stream Hydrology: An Introduction for Ecologists, 2nd ed.; Wiley: New York, NY, USA, 1992; ISBN 978-0-470-84358-1.

18. Simon, A.; Downs, P.W. An Interdisciplinary Approach to Evaluation of Potential Instability in Alluvial Channels. Geomorphology 1995, 12, 215-232. [CrossRef]

19. Thorne, C.R.; Allen, R.G.; Simon, A. Geomorphological River Channel Reconnaissance for River Analysis, Engineering, and Management. Trans. Inst. Br. Geogr. 1996, 21, 469-483. [CrossRef]

20. Johnson, P.A.; Gleason, G.; Hey, R.D. Rapid Assessment of Channel Stability in Vicinity of Road Crossing. J. Hydraul. Eng. 1999, 125, 645-651. [CrossRef]

21. Tubaldi, E.; Macorini, L.; Izzuddin, B.A.; Manes, C.; Laio, F. A Framework for Probabilistic Assessment of Clear-Water Scour around Bridge Piers. Struct. Saf. 2017, 69, 11-22. [CrossRef]

22. Barbetta, S.; Camici, S.; Moramarco, T. A Reappraisal of Bridge Piers Scour Vulnerability: A Case Study in the Upper Tiber River Basin (Central Italy). J. Flood Risk Manag. 2017, 10, 283-300. [CrossRef]

23. Manfreda, S.; Link, O.; Pizarro, A. A Theoretically Derived Probability Distribution of Scour. Water 2018, 10, 1520. [CrossRef]

24. Lagasse, P.F.; Schall, J.D.; Johnson, F.; Richardson, E.V.; Richardson, J.R.; Chang, F. Stream Stability at Highway Structures, 2nd ed.; Department of Transportation, Federal Highway Administration: Washington, DC, USA, 1995.

25. Rosgen, D.L. A Stream Channel Stability Assessment Methodology. Available online: http://www.u-s-c.org/ html/documents/streamstability.pdf (accessed on 1 September 2019).

26. Montgomery, D.R.; MacDonald, L.H. Diagnostic Approach to Stream Channel Assessment and Monitoring. J. Am. Water Resur. Assoc. 2002, 38, 1-16. [CrossRef]

27. Johnson, P.A. Preliminary Assessment and Rating of Stream Channel Stability. J. Hydraul. Eng. 2005, 131, 845-852. [CrossRef]

28. Shields, F.D., Jr.; Copeland, R.R.; Klingeman, P.C.; Doyle, M.W.; Simon, A. Design for Stream Restoration. J. Hydraul. Eng. 2003, 129, 575-584. [CrossRef]

29. Pizarro, A.; Ettmer, B.; Manfreda, S.; Rojas, A.; Link, O. Dimensionless Effective Flow Work for Estimation of Pier Scour Caused by Flood Waves. J. Hydraul. Eng. 2017, 143, 06017006. [CrossRef]

30. Pizarro, A.; Samela, C.; Fiorentino, M.; Link, O.; Manfreda, S. BRISENT: An Entropy-Based Model for Bridge-Pier Scour Estimation under Complex Hydraulic Scenarios. Water 2017, 9, 889. [CrossRef] 
31. Lu, J.Y.; Hong, J.H.; Su, C.C.; Wang, C.Y.; Lai, J.S. Field Measurements and Simulation of Bridge Scour Depth Variations during Floods. J. Hydraul. Eng. 2008, 134, 810-821. [CrossRef]

32. Su, C.C.; Lu, J.Y. Measurements and Prediction of Typhoon-Induced Short-Term General Scours in Intermittent Rivers. Nat. Hazards 2013. [CrossRef]

33. Hong, J.H.; Guo, W.D.; Chiew, Y.M.; Chen, C.H. A New Practical Method to Simulate Flood-Induced Bridge Pier Scour-A Case Study of Mingchu Bridge Piers on the Cho-Shui River. Water 2016, 8, 238. [CrossRef]

34. Sturm, T.; Sotiropoulos, F.; Landers, M.; Gotvald, T.; Lee, S.; Ge, L.; Navarro, R.; Escauriaza, C. Laboratory and 3D Numerical Modeling with Field Monitoring of Regional Bridge Scour in Georgia; Georgia Department of Transportation Final Project, Project, No. 2002; Georgia Department of Transportation: Atlanta, GA, USA, 2004.

35. Crotti, G.; Cigada, A. Scour at River Bridge Piers: Real-Time Vulnerability Assessment through the Continuous Monitoring of a Bridge over the River Po, Italy. J. Civ. Struct. Health Monit. 2019. [CrossRef]

36. Bekić, D.; McKeogh, E.; Kerin, I.; Hand, S.; Bruton, G. Experiences from Bridge Scour Inspections by Using Two Assessment Methods on 100 Railway Bridges. In Proceedings of the 2nd International Conference on Road and Rail Infrastructure CETRA 2012, Dubrovnik, Croatia, 7-9 May 2002; pp. 499-505.

37. U.S. Department of Agriculture-Forest Service. Bridge Scour Evaluation: Screening, Analysis and Countermeasures; U.S. Department of Agriculture-Forest Service: Washington, DC, USA, 1998.

38. The Highways Agency. Assessment of Scour at Highway Bridges, Design Manual for Roads and Bridges BA 74/06; The Highways Agency: London, UK, 2006.

39. Helmerich, R.; Niederleithinger, E.; Algernon, D.; Streicher, D.; Wiggenhauser, H. Bridge Inspection and Condition Assessment in Europe. Transp. Res. Rec. J. Transp. Res. Board 2008, 2044, 31-38. [CrossRef]

40. Bekić, D.; Kerin, I.; Cahill, P.; Michalis, P.; Lapthorne, J.; Šolman, H.; Gilja, G.; Potocki, K.; Pakrashi, V.; McKeogh, E. BRIDGE SMS-Innovative Solution for Management of Bridges Over Water. In Proceedings of the 5th International Conference on Road and Rail Infrastructure (CETRA 2018), Zadar, Croatia, 17-19 May 2018.

41. Quirk, L.; Matos, J.; Murphy, J.; Pakrashi, V. Visual Inspection and Bridge Management. J. Struct. Infrastruct. Eng. 2018, 14, 320-332. [CrossRef]

42. Akay, H.; Baduna Kocyigit, M. Hydrologic Assessment Approach for River Bridges in Western Black Sea Basin, Turkey. J. Perform. Constr. Fac. 2019, in press.

43. Melton, M.A. An Analysis of the Relations among the Elements of Climate, Surface Properties and Geomorphology; Technical Report 11; Department of Geology, Columbia University Office of Navy Research: New York, NY, USA, 1957.

44. Jackson, L.E., Jr.; Kostaschuk, R.A.; MacDonald, G.M. Identification of Debris Flow Hazard on Alluvial Fans in the Canadian Rocky Mountains. Geol. Soc. Am. Rev. Eng. Geol. 1987, VII, 115-124.

45. Demir, G. Experimental Investigation of Scouring Under Skewed Bridge Deck in Pressurized and Weir Type of Flow. Master's Thesis, Gazi University, Ankara, Turkey, 2018. (In Turkish).

46. Gaudio, R.; Grimaldi, C.; Tafarojnoruz, A.; Calomino, F. Comparison of Formulae for the Prediction of Scour Depth at Piers. In Proceedings of the First European IAHR Congress, Edinburgh, UK, 4-6 May 2010.

47. Gaudio, R.; Tafarojnoruz, A.; De Bartolo, S. Sensitivity Analysis of Bridge Pier Scour Depth Predictive Formulae. J. Hydroinform. 2013, 15, 939-951. [CrossRef]

48. Caner, A.; Yanmaz, A.M.; Yakut, A.; Avsar, O.; Yilmaz, T. Service Life Assessment of Existing Highway Bridges with no Planned Regular Inspections. J. Perform. Constr. Fac. 2008, 22, 108-114. [CrossRef]

49. Berk, A. Development of a Safety-Inspection Methodology for River Bridges. Master's Thesis, Middle East Technical University, Ankara, Turkey, 2006.

50. Yanmaz, A.M.; Caner, A.; Berk, A. Renovation of a Safety-Inspection Methodology for River Bridges. J. Perform. Constr. Fac. 2007, 21, 382-389. [CrossRef]

51. Pearson, D.; Stein, S.; Jones, J.S. HYRISK Methodology and User Guide; Federal Highway Administration Rep. FHWA-RD-02-XXX; Federal Highway Administration: Washington, DC, USA, 2002. 
52. Yanmaz, A.M.; Apaydin, M. Bridge Scour Risk Assessment and Countermeasure Design. J. Perform. Constr. Fac. 2012, 26, 499-506. [CrossRef]

53. Robert, W.E.; Marshall, A.R.; Shepard, R.W.; Aldayuz, J. Pontis Bridge Management System. In Proceedings of the 9th International Bridge Management Conference, Orlando, FL, USA, 28-30 April 2003.

(C) 2019 by the authors. Licensee MDPI, Basel, Switzerland. This article is an open access article distributed under the terms and conditions of the Creative Commons Attribution (CC BY) license (http://creativecommons.org/licenses/by/4.0/). 